medRxiv preprint doi: https://doi.org/10.1101/2021.06.12.21256778; this version posted June 20, 2021. The copyright holder for this preprint (which was not certified by peer review) is the author/funder, who has granted medRxiv a license to display the preprint in perpetuity. It is made available under a CC-BY-ND 4.0 International license .

\title{
De novo FZR1 loss-of-function variants cause developmental and epileptic encephalopathies including Myoclonic Atonic Epilepsy
}

Sathiya N. Manivannan ${ }^{1,2}$, Jolien Roovers ${ }^{3,4}$, Noor Smal ${ }^{5}$, Candace T. Myers ${ }^{6}$, Dilsad Turkdogan $^{7}$, Filip Roelens ${ }^{8}$, Oguz Kanca ${ }^{1,2}$, Hyung-Lok Chung ${ }^{1,2}$, Tasja Scholz ${ }^{9}$, Katharina Hermann $^{10}$, Tatjana Bierhals ${ }^{9}$, S. Hande Caglayan ${ }^{11}$, Hannah Stamberger ${ }^{5,12}$, MAE working group of EuroEPINOMICS RES Consortium,_Heather Mefford ${ }^{6}$, Peter de Jonghe ${ }^{3,4,12}$, Shinya Yamamoto $^{1,2,13,14,15, *}$, Sarah Weckhuysen ${ }^{5,12,16, *}$, Hugo J. Bellen ${ }^{1,2,13,14,15,17, *}$

\section{Affiliation}

1'Department of Molecular and Human Genetics, Baylor College of Medicine (BCM), Houston, TX 77030, USA.

${ }^{2} J a n$ and Dan Duncan Neurological Research Institute, Texas Children's Hospital, Houston, 77030, USA.

${ }^{3}$ Neurogenetics group, VIB Center for Molecular Neurology, VIB, Antwerp, 2610, Belgium.

${ }^{4}$ Laboratory of Neurogenetics, Institute Born-Bunge, University of Antwerp, Antwerp, 2610, Belgium.

${ }^{5}$ Applied\&Translational Neurogenomics Group, VIB Center for Molecular Neurology, VIB, Antwerp, 2610, Belgium.

${ }^{6}$ Center for Pediatric Neurological Disease Research, Department of Cell \& Molecular Biology St. Jude Children's Research Hospital, Memphis, TN 30105

${ }^{7}$ Division of Child Neurology, Department of Pediatrics, Marmara University, Faculty of Medicine, Turkey.

${ }^{8}$ Child Neurology, AZ Delta, Roeselare, Belgium.

${ }^{9}$ Institute of Human Genetics, University Medical Center Hamburg-Eppendorf, 20251, Hamburg, Germany. 
medRxiv preprint doi: https://doi.org/10.1101/2021.06.12.21256778; this version posted June 20, 2021. The copyright holder for this preprint (which was not certified by peer review) is the author/funder, who has granted medRxiv a license to display the preprint in perpetuity. It is made available under a CC-BY-ND 4.0 International license .

${ }^{10}$ Department of Pediatrics, University Medical Center Hamburg-Eppendorf, 20251, Hamburg, Germany

${ }^{11}$ Department of Molecular Biology and Genetics, Bogazici University, Istanbul, Turkey.

${ }^{12}$ Department of Neurology, University Hospital Antwerp, Antwerp, 2650, Belgium.

${ }^{13}$ Department of Neuroscience, BCM, Houston, TX 77030, USA.

${ }^{14}$ Program in Developmental Biology, BCM, Houston, TX 77030, USA.

${ }^{15}$ Development, Disease Models \& Therapeutics Graduate Program, BCM, Houston, TX 77030, USA.

${ }^{16}$ Translational Neurosciences, Faculty of Medicine and Health Science, University of Antwerp, Antwerp, 2650, Belgium.

${ }^{17}$ Howard Hughes Medical Institute, Baylor College of Medicine, Houston, TX 77030, USA.

${ }^{*}$ Corresponding authors:

Sarah Weckhuysen: +32 32651870 sarah.weckhuysen@uantwerpen.vib.be

Hugo J. Bellen: +1-713-798-5272, hbellen@bcm.edu

Myoclonic Atonic Epilepsy (MAE) working group of EuroEPINOMICS RES Consortium:

Dana Craiu (Pediatric Neurology Clinic II, Department of Neurology, Pediatric Neurology, Psychiatry, Neurosurgery, Carol Davila (University of Medicine, Bucharest, Romania; Pediatric Neurology Clinic), Ingo Helbig (Department of Neuropediatrics, University Medical Center Schleswig-Holstein, Christian Albrechts University, Kiel, Germany), Renzo Guerrini (Pediatric Neurology Unit and Laboratories, Children's Hospital A. Meyer, University of Florence, Florence, Italy), Anna-Elina Lehesjoki (Folkhälsan Institute of Genetics, Helsinki, Finland; Research Programs Unit, Molecular Neurology and Neuroscience Center, University of Helsinki, Helsinki, Finland), Carla Marini (Pediatric Neurology Unit and Laboratories, Children's Hospital A. Meyer, 
medRxiv preprint doi: https://doi.org/10.1101/2021.06.12.21256778; this version posted June 20, 2021. The copyright holder for this preprint (which was not certified by peer review) is the author/funder, who has granted medRxiv a license to display the preprint in perpetuity. It is made available under a CC-BY-ND 4.0 International license .

University of Florence, Florence, Italy), Hiltrud Muhle (Department of Neuropediatrics, University Medical Center Schleswig-Holstein, Christian Albrechts University, Kiel, Germany), Rikke S Møller (Danish Epilepsy Centre, Dianalund, Denmark), Bernd Neubauer (Department of Neuropediatrics, University Medical Faculty Giessen and Marburg, Giessen, Germany), Deb Pal (Department of Clinical Neuroscience, Institute of Psychiatry, King's College London, London, UK), Katalin Sterbova (Child Neurology Department, University Hospital Motol, Prague, Czech Republic), Pasquale Striano (Pediatric Neurology and Muscular Diseases Unit, Department of Neurosciences, Rehabilitation, Ophthalmology, Genetics, Maternal and Child Health, 'G Gaslini Institute', Genova, Italy), Tiina Talvik (Department of Pediatrics, University of Tartu, Tartu, Estonia; Department of Neurology and Neurorehabilitation, Children's Clinic, Tartu University Hospital, Tartu, Estonia), Sarah von Spiczak (Department of Neuropediatrics, University Medical Center Schleswig-Holstein, Christian Albrechts University, Kiel, Germany), Hande Caglayan (Department of Molecular Biology and Genetics Istanbul, Boğaziçi University, Istanbul, Turkey), Yvonne Weber (Department of Neurology and Epileptology, Hertie Institute for Clinical Brain Research, University of Tübingen, Tübingen, Germany), Dorota Hoffman-Zacharska (Department of Medical Genetics, Institute of Mother and Child, Warsaw, Poland). 
medRxiv preprint doi: https://doi.org/10.1101/2021.06.12.21256778; this version posted June 20, 2021. The copyright holder for this preprint (which was not certified by peer review) is the author/funder, who has granted medRxiv a license to display the preprint in perpetuity.

It is made available under a CC-BY-ND 4.0 International license .

\section{Abstract}

FZR1, which encodes the Cdh1 subunit of the Anaphase Promoting Complex, plays an important role in neurodevelopment by regulating cell cycle and by its multiple post-mitotic functions in neurons. In this study, evaluation of 250 unrelated patients with developmental epileptic encephalopathies (DEE) and a connection on GeneMatcher led to the identification of three de novo missense variants in FZR1. Two variants led to the same amino acid change. All individuals had a DEE with childhood onset generalized epilepsy, intellectual disability, mild ataxia and normal head circumference. Two individuals were diagnosed with the DEE subtype Myoclonic Atonic Epilepsy (MAE). We provide gene burden testing using two independent statistical tests to support FZR1 association with DEE. Further, we provide functional evidence that the missense variants are loss-of-function (LOF) alleles using Drosophila neurodevelopment assays. Using three fly mutant alleles of the Drosophila homolog fzr and overexpression studies, we show that patient variants do not support proper neurodevelopment. With the recent report of a patient with neonatal-onset DEE with microcephaly who also carries a de novo FZR1 missense variant, our study consolidates the relationship between $F Z R 1$ and DEE, and expands the associated phenotype. We conclude that heterozygous LOF of FZR1 leads to DEE associated with a spectrum of neonatal to childhood onset seizure types, developmental delay and mild ataxia. Microcephaly can be present but is not an essential feature of $F Z R 1$-encephalopathy. In summary, our approach of targeted sequencing using novel gene candidates and functional testing in Drosophila will help solve undiagnosed MAE/DEE cases. 
medRxiv preprint doi: https://doi.org/10.1101/2021.06.12.21256778; this version posted June 20, 2021. The copyright holder for this preprint (which was not certified by peer review) is the author/funder, who has granted medRxiv a license to display the preprint in perpetuity. It is made available under a CC-BY-ND 4.0 International license .

\section{Introduction}

Developmental and Epileptic Encephalopathies (DEEs) are a heterogeneous group of disabling disorders, characterized by a combination of severe epilepsy and neurodevelopmental problems $^{1}$. Seizures in DEE patients usually have an early age-of-onset and are often refractory to anti-epileptic drugs. The majority of DEE cases are thought to have a genetic basis, usually in the form of rare de novo variants with a highly disruptive effect on gene expression or protein function. Pathogenic variants in more than a hundred genes have been associated with a DEE phenotype so $\operatorname{far}^{2-4}$. Identifying the causal variant in a DEE patient can bring an end to an often long and stressful diagnostic odyssey and may lead to improved or targeted treatment for a subset of the cases $2 ; 5 ; 6$.

We set out to identify novel variants in DEE patients by screening a large cohort of patients with Myoclonic Atonic Epilepsy (MAE), a sub-type of DEE, as part of the efforts of the EuroEPINOMICS-RES consortium ${ }^{7}$. MAE is characterized by generalized seizure types including myoclonic, atonic, myoclonic atonic, absence and tonic-clonic seizures. The seizure onset is typically between 7 months and 6 years $^{8}$. Using a combination approach of trio wholeexome sequencing (WES) and subsequent screening with a targeted gene panel including candidate genes for MAE, we identified two individuals diagnosed with MAE who each carried a unique de novo missense variant in FZR1. A third individual with a DEE with childhood onset generalized epilepsy and a de novo missense variant was identified through GeneMatcher.

FZR1 (fizzy and cell division cycle 20 related 1, MIM:603619) encodes Cdh1, one of the two regulatory subunits of the Anaphase Promoting Complex (APC) that confers the substratespecificity on this E3 ubiquitin ligase complex ${ }^{9}$. APC was initially identified to play a key role in mitotic cell cycle progression ${ }^{10}$. When Cdh1 associates with APC (Cdh1-APC), it controls mitotic exit leading to $\mathrm{G} 1$ arrest $^{11}$. Cdh1/Fzr1 knockout in mice leads to embryonic lethality, suggesting that this gene plays critical roles in development in vivo in mammals ${ }^{12}$. These Fzr1 knockout 
medRxiv preprint doi: https://doi.org/10.1101/2021.06.12.21256778; this version posted June 20, 2021. The copyright holder for this preprint (which was not certified by peer review) is the author/funder, who has granted medRxiv a license to display the preprint in perpetuity. It is made available under a CC-BY-ND 4.0 International license.

mice, which die as embryos, have impaired cortical neurogenesis due to delay of mitotic exit, leading to reduced cortical size and thickness ${ }^{13}$. Cdh1-APC also has a prominent function in post-mitotic cells in the nervous system ${ }^{14}$. It controls neuronal survival ${ }^{15 ; 16}$, axonal growth ${ }^{17}$, and synapse formation and function ${ }^{18}$. Similar to its mammalian counterpart, the Drosophila homolog of FZR1, fzr (fizzy-related), has been studied in the context neurodevelopment in addition to its role in cell-cycle regulation as part of the APC ${ }^{17 ; 19-21} . f z r$ is necessary for photoreceptor patterning and regulates glial cell migration from the brain into the eye imaginal disc ${ }^{17}$. Through a forward genetic screen, we previously isolated two fzr alleles which displayed abnormal retina pattern and defects in electroretinograms $(E R G)^{22}$. These phenotypes have been reported in hypomorphic mutants of $f z r$ which were first identified through their rough eyes, leading to one of the gene's synonyms 'retina aberrant in pattern $(r a p)^{, 23}$. These previously generated $f z r$ alleles provide genetic tools to test the functionality of the human $F Z R 1$ variants identified in DEE patients.

During the course of our study, a different rare variant in FZR1 was reported in an individual with microcephaly and $\mathrm{DEE}^{24}$. This study showed that the missense variant found in their patient led to decreased stability of the FZR1 protein in patient leukocytes and in HEK293T cells as well as accumulation of proteins targeted by $\mathrm{Cdh} 1-\mathrm{APC}^{24}$. The mutant protein was also unable to rescue the aberrant cell cycle distribution of primary cortical progenitors from Cdh1/Fzr1 knockout mice. Based on these data, the authors argued that this variant potentially contributes to microcephaly in the patient.

Here, we present three individuals with DEE and a novel de novo missense variant in FZR1. These cases consolidate the role of $F Z R 1$ in DEE and expand the phenotypic spectrum of FZR1-related encephalopathy to DEE with childhood onset generalized epilepsy, mild ataxia and normal head circumference. To determine the functional consequence of the missense variants, we assessed the ability of the variant proteins to rescue the eye phenotype of the fly 
medRxiv preprint doi: https://doi.org/10.1101/2021.06.12.21256778; this version posted June 20, 2021. The copyright holder for this preprint (which was not certified by peer review) is the author/funder, who has granted medRxiv a license to display the preprint in perpetuity. It is made available under a CC-BY-ND 4.0 International license .

fzr mutant alleles isolated from a forward genetic screen using mosaic analysis. Furthermore, we also generated a new loss-of-function allele of $f z r$ using the CRIMIC technology ${ }^{25}$ to study the impact of the patients' variants during development. Through these assays in Drosophila, we provide functional evidence for a LOF mechanism of the pathogenic variants found in our patients, further supporting the involvement of FZR1 in MAE.

\section{Subjects and methods}

\section{Identification of patients with de novo FZR1 variants}

Patient 1 was recruited to the project on MAE of the EuroEPINOMICS-RES consortium ${ }^{7}$. WES was performed on an initial cohort of 39 parent-offspring trios (including Patient 1) with MAE at the Wellcome Trust Sanger Institute (Hinxton, Cambridgeshire). WES and subsequent data analyses were performed as previously described ${ }^{26}$. The GenomeComb program was used for annotation and filtering of the data ${ }^{27}$. Coding variants that lead to a missense change, stop gain or stop loss, frameshift or essential splicing change were retained for further filtering. Variants that were present in the $\operatorname{ExAC}^{28}$ and Genome Aggregation Database (gnomad, v2.1.1) ${ }^{29}$ with a frequency $>0.01$ or $>0$ for homozygous and X-chromosome or heterozygous variants respectively were excluded. We also excluded variants in genes that are not expressed in the brain in the Genotype-Tissue Expression project database (GTEx V8) ${ }^{30}$. Pathogenicity of missense variants was predicted using the Combined Annotation Dependent Depletion scores $(C A D D, v 1.6)^{31}$ and missense variants with a CADD-score $<20$ were excluded. All remaining candidate variants following a recessive, de novo or X-linked inheritance were validated using Sanger sequencing.

Patient 2 was part of a follow-up cohort consisting of 211 DEE patients, including 89 probands with MAE, and 122 probands with Dravet or Dravet-like syndrome. The cohort was screened using a targeted gene panel using Molecular Inversion Probes and consisted of the coding regions of 12 known and 40 candidate genes (at time of screening) for MAE, including FZR1 
medRxiv preprint doi: https://doi.org/10.1101/2021.06.12.21256778; this version posted June 20, 2021. The copyright holder for this preprint (which was not certified by peer review) is the author/funder, who has granted medRxiv a license to display the preprint in perpetuity.

It is made available under a CC-BY-ND 4.0 International license .

(see supplemental Table 1). Candidate genes included in this panel were selected from a list of genes with single de novo hits identified in the EuroEPINOMICS-RES WES data. Data analysis and variant filtering was performed as previously described ${ }^{32}$. Segregation analysis was performed using Sanger sequencing for all nonsynonymous, frameshift, and splice-site variants that were not present in the ExAC set of $\sim 61,000 \mathrm{WES}^{28}$. Paternity and maternity were confirmed using the Powerplex®16S system (Promega).

Patient 3 was identified through GeneMatcher ${ }^{33}$. Trio-WES was performed in a clinical diagnostic setting using DNA from the patient and both healthy parents. Trio-exome data were filtered for non-synonymous de novo variants absent in the general population (gnomAD), and for rare biallelic variants with minor allele frequency (MAF) $<0.1 \%$ and absence of homozygous carriers in the aforementioned database. The functional impact of the identified missense variants was predicted using the CADD, v1.6 $6^{31} \mathrm{SIFT}^{34}$ and Polyphen ${ }^{35}$ pathogenicity prediction tools.

The Ethical Committee of the University of Antwerp, Belgium gave ethical approval for the study. Parents of each patient signed an informed consent form for participation in the study.

\section{Gene burden analysis}

A gene burden analysis was performed using denovolyze $\mathrm{R}^{36}$ for the two de novo missense variants identified in the combined research cohort of 250 patients examined in our study. In parallel, we determined the number of rare, potential damaging variants in $F Z R 1$ in the control population set of gnomAD ${ }^{28}$ based on $\mathrm{CADD}^{31}, \mathrm{SIFT}^{34}$ and Polyphen ${ }^{35}$ scores using the Variant Effect Predictor tool from Ensembl ${ }^{37}$. We filtered missense variants and loss-of-function variants that had a general population frequency of less than or equal to 0.01 , had a CADD score greater than or equal to 20 , and were predicted to be Pathogenic/Likely pathogenic by SIFT and Polyphen. We performed a chi-square test to evaluate the allele-count burden as well as 
medRxiv preprint doi: https://doi.org/10.1101/2021.06.12.21256778; this version posted June 20, 2021. The copyright holder for this preprint (which was not certified by peer review) is the author/funder, who has granted medRxiv a license to display the preprint in perpetuity. It is made available under a CC-BY-ND 4.0 International license .

number of unique variant burden in the DEE patient cohorts compared to the gnomAD (control) population.

\section{Evaluation of relative positions of affected residues in the 3D structural model of human Cdh1}

To examine the localization of the residues predicted to be altered by the patients' missense variants, we used the 3D structural model of Cdh1 generated from an electron microscopy reconstruction of the Homo sapiens APC (PDB ID:4ui9) ${ }^{9}$. We used PyMOL (Molecular Graphics System, Version 2.0 Schrödinger, LLC). to map the location of the residues affected. We also predicted the location of the Drosophila $\mathrm{Fzr}^{\mathrm{A}}$ variant based on the homology of human FZR1 and Drosophila Fzr proteins (Figure S2A).

\section{Functional assessment of DEE-associated missense variants in Drosophila melanogaster}

The molecular lesions of two EMS-induced variants identified from our previous forward genetic screen ${ }^{22}, f z r^{A}$ and $f z r^{B}$, were identified using Sanger sequencing of PCR amplicons of genomic DNA ${ }^{38}$. ERG analysis on mosaic adult eye were performed as described earlier ${ }^{39}$. We used CRISPR/Cas9 technology to insert a T2A-GAL4 gene trap cassette based on CRISPR mediated Integration Cassette (CRIMIC) technology into the intron of $f z r$ at ChrX:4,676,058 (Drosophila melanogaster reference genome, Assembly 6) and generated the fzr CR00643-TG4.2 allele (referred in the text as $f \not r^{T 2 A-G A L 4}$ ). Expression of GAL4 from the $f z r^{T 2 A-G A L 4}$ allele was examined using a UAS-nls::RFP reporter [Bloomington Drosophila Stock Center (BDSC) stock number: 8546). Complementation tests were performed using the $f z r^{j e 28}$ allele $^{19}$ (a kind gift from Dr. Christian Klambt) and $D p(1 ; 3) D C 472 \mathrm{P}$ [acman] clone inserted in the third chromosome at the VK33 docking site ${ }^{40-42}$. To perform rescue experiments of $f z r$ mutants, we subcloned the full length $f z r$ cDNA from a pUASt-fzr vector ${ }^{19}$. Drosophila fzr cDNA carrying the variants at positions corresponding to the human variants were generated by site-directed mutagenesis using QuickChange II kit (Agilent). As patient 2 and patient 3 carry a variant affecting the same 
medRxiv preprint doi: https://doi.org/10.1101/2021.06.12.21256778; this version posted June 20, 2021. The copyright holder for this preprint (which was not certified by peer review) is the author/funder, who has granted medRxiv a license to display the preprint in perpetuity. It is made available under a CC-BY-ND 4.0 International license .

nucleotide and leading to the same protein change, only the $C>G$ variant of patient 2 was modeled. Wild-type (wt) and mutant fzr expressing UAS constructs were integrated into VK33 docking site on the fly third chromosome via phiC31 transgenics ${ }^{40}$. Transgenic lines were recovered and established based on standard crossing schemes ${ }^{43}$. Rescue experiments for eye phenotypes of $f z r^{B}$ mutants were performed using the MARCM (Mosaic analysis with a repressible cell marker) technique ${ }^{44}$. MARCM-based rescue was achieved by crossing flies of the following genotype: $y w f z r^{B}, F R T 19 A / F M 7 c, K r-G A L 4$, UAS-GFP (BDSC 52385) and tubGAL80, ey-FLP, FRT19A/Y; Act-GAL4, UAS-GFP/CyO (FRT19A tester line). The FRT19A tester line was generated by crossing the following stocks tub-Gal80, ey-FLP, FRT19A (BDSC 42717) and FRT19A; Act5C-GAL4, UAS-GFP/CyO (BDSC 42726). Rescue of the lethality of the $f Z r^{T 2 A-G A L 4}$ allele was assessed based on the T2A-GAL4 strategy ${ }^{25 ;} 45$, and achieved by setting the following cross: $f z r^{T 2 A-G A L 4} / F M 7, A c t-G F P$ crossed to UAS-fzr (wt or variant) and evaluation of non-GFP male larvae at late third instar stage. Overexpression studies in the developing eye imaginal disc were carried out using ey3.5-GAL4 ( $y^{1} w^{1118} ; P\{$ ey3.5-GAL4.Exel\}2) (BDSC: $8220)^{17}$.

\section{Electroretinogram analysis of adult mosaic eyes}

$y w f z r^{B}, F R T 19 A / F M 7 c, K r-G A L 4$, UAS-GFP and $y w f z r^{A}, F R T 19 A / F M 7 c, K r-G A L 4$, UAS-GFP (BDSC 52384) females were crossed with y w FRT19A; ey-FLP (BDSC 5579). The resulting females carried mosaic eyes with mutants identifiable with the lack of red pigmentation. ERG analysis on mosaics were performed as described earlier ${ }^{22 ; 39}$.

\section{Immunofluorescence analysis of Drosophila tissue}

Immunofluorescence analysis was performed as described earlier on embryos and third instar larval eye imaginal discs ${ }^{17 ; 19}$. The following antibodies from Developmental Studies Hybridoma Bank (University of lowa) or commercial sources were used: mouse anti-Repo $(1: 50,8 D 12)^{46}$, rat anti-ELAV (1:50, 7E8A10 $)^{47}$, rabbit anti-HRP (1:50, Jackson ImmunoResearch, \#323-005- 
medRxiv preprint doi: https://doi.org/10.1101/2021.06.12.21256778; this version posted June 20, 2021. The copyright holder for this preprint (which was not certified by peer review) is the author/funder, who has granted medRxiv a license to display the preprint in perpetuity. It is made available under a CC-BY-ND 4.0 International license .

021), chicken anti-GFP (1:1000, Abcam ab13970), rabbit anti-mCherry (1:500, Abcam ab167453), Alexa488 conjugated goat anti-Chicken (1:200, ThermoFisher A-11039), Alexa647 conjugated goat anti-mouse (1:250, Abcam ab150115), Alexa647 conjugated goat anti-rat (1:250, Abcam ab150159), Alexa594 conjugated goat anti-rabbit (1:1000, ThermoFisher A11012), Alexa405 conjugated goat anti-rabbit (1:100, ThermoFisher A-31556). Samples were imaged using a LSM 500 confocal microscope (Zeiss) to generate a Z-stack of different focal planes. The confocal Z-stack images were used to generate maximum intensity Z-projection using Image $J^{48}$.

\section{Mammalian overexpression vectors, cell culture, Immunofluorescence, and western blot}

Human FZR1 cDNA (NM_001136198.1) in the donor vector pDONR221 (HsCD00042756;) was purchased from Harvard cDNA clone repository. The coding region was cloned into the pEzy-eGFP (Addgene \#18671) destination vector in frame with an N-terminal eGFP tag using Gateway $^{\mathrm{TM}}$ LR Clonase $^{\mathrm{TM}}$ II Enzyme mix (ThermoFisher 11791020) following the manufacturer's recommended protocol. The variants observed in the DEE patients were introduced into the pEzy-eGFP-FZR1 using Quickchange II site directed mutagenesis kit (Agilent).

Human embryonic kidney cells (HEK293) were grown in Dulbecco's Modified Eagle's Medium (DMEM; Thermofisher) supplemented with $10 \%$ fetal bovine serum. Cells were transfected with overexpression vectors using Lipofectamine 3000 reagent (ThermoFisher) with OptiMEM media (Thermofisher) using the manufacturer's recommended protocol. Cells were fixed using $4 \%$ Paraformaldehyde in PBS at room temperature. Immunofluorescence staining was performed using chicken anti-GFP antibody (1:1000, Abcam ab13970) as described earlier ${ }^{49}$. Nucleus and actin-cytoskeleton were visualized using DAPI (4',6-diamidino-2-phenylindole, ThermoFisher D1306) and Alexa647 conjugated Phalloidin (Cell signaling, \#8940) respectively. Cells were imaged using Zeiss LSM 500 confocal microscope. A 2-micron optical section with the nucleus 
medRxiv preprint doi: https://doi.org/10.1101/2021.06.12.21256778; this version posted June 20, 2021. The copyright holder for this preprint (which was not certified by peer review) is the author/funder, who has granted medRxiv a license to display the preprint in perpetuity. It is made available under a CC-BY-ND 4.0 International license .

in focus were obtained. Protein isolation and western blot analysis was performed 36 hours post transfection as described earlier ${ }^{49}$. Chicken anti-GFP $\left(1: 1000\right.$, Abcam ab13970) and IRDye ${ }^{\circledR}$ 800CW donkey anti-chicken Secondary Antibody (LiCOR P/N: 926-32218) were used for detecting N-terminal GFP tagged FZR1 protein.

\section{Primers used in the study}

\begin{tabular}{l|l|}
\hline \multicolumn{1}{|c|}{ Name } & Sequence (5' to $\mathbf{3}^{\prime}$ ) \\
\hline FP.FZR1.C999G & CCAGCTCCTCGCCTCGGAGGGCAAGGACAACAAGCTGCTGGTCTG \\
\hline FP.FZR1.G559A & GACGCGCCCGAGCTGCAGGACAACTTCTACCTCAATCTGGTG \\
\hline RP.FZR1.C999G & CAGACCAGCAGCTTGTTGTCCTTGCCCTCCGAGGCGAGGAGCTGG \\
\hline RP.FZR1.G559A & CACCAGATTGAGGTAGAAGTTGTCCTGCAGCTCGGGCGCGTC \\
\hline $\begin{array}{l}\text { FP.fzr.flycDNA- } \\
\text { c.G514A }\end{array}$ & GACGCGCCCGAGTTGCAGGACAACTTCTATCTGAACCTGGTC \\
\hline $\begin{array}{l}\text { RP.fzr.flycDNA- } \\
\text { c.G514A }\end{array}$ & GACCAGGTTCAGATAGAAGTTGTCCTGCAACTCGGGCGCGTC \\
\hline $\begin{array}{l}\text { FP.fzr.flycDNA- } \\
\text { c.C954G }\end{array}$ & CAATACTTGGCCAGTGGCGGCAAGGATAATCGGTTGTATGTGTGG \\
\hline RP.fzr.flycDNA- & CCACACATACAACCGATTATCCTTGCCGCCACTGGCCAAGTATTG \\
\hline c.C954G & \\
\hline FP.rap.mut.map1 & CAACACCGCAATACATAGAGCAACC \\
\hline RP.rap.mut.map1 & CTCGTGCAGAGTTCAATGCACC \\
\hline FP.rap.mut.map2 & CATCGCATTAACATTTCCGTGCTTCC \\
\hline RP.rap.mut.map2 & GTCAAATTCGCTGACCTTTCAGCTTG \\
\hline FP.rap.mut.map3 & GGGCCGCAAACAAAGCAAAC \\
\hline RP.rap.mut.map3 & CCACATCCCAGACGGTCACG \\
\hline FP.rap.mut.map4 & CCGGATGCGAATACGGTGAC \\
\hline RP.rap.mut.map4 & AGTAGCCGTGCGTGGAGAC \\
\hline FP.rap.mut.map5 & GGCGGTGGAACGGCG \\
\hline RP.rap.mut.map5 & AGATTCAGAACGGACTTGTTCTCCTTC \\
\hline FP.rap.mut.map6 & GTGGAAATATCCCTCCCTGACGC \\
\hline RP.rap.mut.map6 & TGCTGCTGTGGGGTCACAC \\
\hline FP.rap.mut.map7 & CTCTTGCAGCCCTCGTACAT \\
\hline FP.rap.mut.map8 & AATGGGGATTTCACATTTTG \\
\hline RP.rap.mut.map7 & GGCCATGCTTGTTTGTTGT \\
\hline RP.rap.mut.map8 & TTGAAACATTTTGTCTATCGATATTTT \\
\hline
\end{tabular}

\section{Results}

\section{Clinical case reports}

A summary of the clinical history of the three patients described above, and the patient described by Rodriguez et al. ${ }^{24}$ can be found in Table 1. In compliance with the privacy rules of 
medRxiv preprint doi: https://doi.org/10.1101/2021.06.12.21256778; this version posted June 20, 2021. The copyright holder for this preprint (which was not certified by peer review) is the author/funder, who has granted medRxiv a license to display the preprint in perpetuity. It is made available under a CC-BY-ND 4.0 International license .

MedRxiv, the details of patient's symptoms, genetic diagnosis and treatment information are available to readers upon a reasonable request to the corresponding author.

WES on patient 1 and unaffected parents yielded a de novo missense variant in FZR1 [c.559G>A, p.(D187N), Table 1] located at the same residue as the previously reported de novo missense variant in a patient with microcephaly, psychomotor retardation, and epilepsy [p.(D187G) $]^{24}$. No other variants passed the filtering steps as described in the methods section. A relative with mild learning disabilities but no seizures did not carry the variant. The variant is not present in the gnomAD database and has a CADD score of $29.7^{31}$, SIFT-score of $0.01,{ }^{34}$ and PolyPhen score of $0.936^{35}$, all indicating a deleterious or probably damaging effect. According to the gnomAD database ${ }^{29}, F Z R 1$ has a pLI score of 1 , o/e score of 0.04 , and a $z$ score of 3.64 for missense variants, showing that this gene is intolerant to both LOF (nonsense, frameshift, core splicing) and missense variants.

Following the identification of a de novo FZR1 missense variant in Patient 1, a follow-up panel-screening resulted in the identification of another de novo FZR1 missense variant [c.999C>G, p.(N333K), Table 1] in Patient 2. This variant had a CADD score of 23.6, SIFTscore of 0.01 and PolyPhen score of $\mathbf{0 . 8 1 4}$, all predicting a deleterious or possibly damaging effect. This variant was also absent from the gnomAD database. Previous genetic tests on this patient included karyotype analysis and SCN1A and $P C D H 19$ screening, all of which were negative. Array-based comparative genomic hybridization (array-CGH) showed two duplications on Chr11p11.2. These copy number variations were inherited from the healthy mother and did not include disease-associated genes. Therefore, they deemed non-contributing to the patient phenotype.

Patient 3 was identified through Genematcher, and carries a de novo missense variant at the same nucleotide position as patient 2 , leading to an identical amino acid change [c.999C>A, 
medRxiv preprint doi: https://doi.org/10.1101/2021.06.12.21256778; this version posted June 20, 2021. The copyright holder for this preprint (which was not certified by peer review) is the author/funder, who has granted medRxiv a license to display the preprint in perpetuity. It is made available under a CC-BY-ND 4.0 International license .

p.(N333K), table 1], with identical CADD, SIFT and PolyPhen scores. Previous chromosome analysis and array-CGH were normal. Filtering of exome data retained homozygous variants in two additional genes, not yet reported in the context of rare Mendelian disorders. The missense variant c.2105_2106delinsTC, p.(S702F) in PTPN21 (NM_007039.4) had a SIFT-score of 0.000 and PolyPhen score of 0.996 , predicting a probably damaging effect. This multinucleotide variant is present twice heterozygous in gnomAD. PTPN21 (Tyrosine-protein phosphatase nonreceptor type 21, MIM: 603271) is an oncogenic protein known to be upregulated in several types of cancer cells ${ }^{50}$ and functions as a key regulator of inflammation ${ }^{51}$. Two non-synonymous single-nucleotide polymorphisms in PTPN21 showed association to schizophrenia in a GWAS study $^{52}$. In neurons, PTPN21 controls the activity of KIF1C, a fast organelle transporter implicated in the transport of dense core vesicles and the delivery of integrins to cell adhesions $^{53}$. It was further shown to positively influence cortical neuronal survival and to enhance neuritic length ${ }^{54}$. The second homozygous variant identified in patient 3 was the truncating variant c.577C>T, p.(R193*) in the last exon of TPD52L2 (NM_199360.3). TPD52L2 (Tumor protein D52-like 2, MIM: 603747) is an ubiquitously expressed tumor protein shown to be involved in multiple membrane trafficking pathways, and to affect cell proliferation, adhesion and invasion ${ }^{55,56}$. As the de novo FZR1 missense variant resulted in the same amino-acid substitution as identified in patient 2 who has a very similar phenotype, we concluded that the FZR1 variant is most likely to underlie the neurological disease of patient 3 . We can however not totally exclude the possibility that the variants in PTPN21 and TPD52L2 contribute to the phenotype of the patient 3.

Having found these cases, we tested the association between rare variants in FZR1 and DEE using two different gene burden analysis tools. First, we used the tool denovolyze ${ }^{36}$ which evaluates the overrepresentation of de novo variants that affect the protein sequence (missense and loss of function variants) in a specific gene. We found that identification of two de novo 
medRxiv preprint doi: https://doi.org/10.1101/2021.06.12.21256778; this version posted June 20, 2021. The copyright holder for this preprint (which was not certified by peer review) is the author/funder, who has granted medRxiv a license to display the preprint in perpetuity.

It is made available under a CC-BY-ND 4.0 International license .

variants in FZR1 amongst the 250 patients in our research cohort is a 212 -fold enrichment (Poisson distribution P-value of 4.41e-05) over the expected number of de novo variants, suggesting a strong association of FZR1 de novo missense variants with the disorder. Second, we compared the rate of rare, damaging variants in our research cohort (250 patients) with that of general population in gnomAD $(141,456 \text { samples })^{29}$ in FZR1. For this, we re-analyzed both the WES dataset and the targeted panel sequencing cohort of our patient population for the presence of damaging, rare variants regardless of inheritance, and did not identify any additional qualifying variants. Once again, we found a significant enrichment in the number of damaging variants in FZR1 within our patient cohort (2/250 patients) compared to that of gnomAD (total allele count $=97$, unique variants $=57$; Chi Square test P-value for unique variants $=1.613 \mathrm{e}-05 ;$ Chi Square test $\mathrm{P}$-value for total allele count $=0.001574)$. These two burden analyses show that, even though only two patients with $F Z R 1$ variants were identified amongst 250 DEE patients within our research cohort, there are strong statistical data to support an association between rare FZR1-missense variants and DEE.

\section{DEE-associated $F Z R 1$ variants lead to reduced ${ }^{57}$ protein abundance}

FZR1 and its homologs in other species are highly conserved with Drosophila Fzr protein showing over $70.3 \%$ identity with human FZR1. The amino acids that are impacted by the missense variants that we identified in the patients are conserved in Drosophila Fzr (Figure 1A, S2A). To test the effect of the patient variants on protein stability and localization, we expressed FZR1 with an N-terminal eGFP tag in HEK293 cells. FZR1 expression was detected in the nucleus, with a weaker diffuse signal in the cytoplasm (Figure 1B). Variant FZR1 proteins showed a similar pattern of localization. However, western blot of total protein from cells transfected with wt or mutant eGFP-FZR1 showed a clear difference in FZR1 abundance, with both patient variants leading to a reduction in protein level of approximately $40 \%(p<0.01)$ (Figure 1C-D). 
medRxiv preprint doi: https://doi.org/10.1101/2021.06.12.21256778; this version posted June 20, 2021. The copyright holder for this preprint (which was not certified by peer review) is the author/funder, who has granted medRxiv a license to display the preprint in perpetuity.

It is made available under a CC-BY-ND 4.0 International license .

To further examine the effect of patient variants on human FZR1 function, we mapped the affected residues in a 3D protein structure of the $\mathrm{APC}^{9}$. Variants found in all three patients affect residues within the WD40 domain of the FZR1 protein (Figure 1E, S2B). WD40 domains, also known as beta transducing repeats, enable protein-protein interactions ${ }^{58}$, and de novo variants in another WD40 repeat containing protein encoding gene WDR37 has also been recently associated with epilepsy ${ }^{59}$. The active site of a WD40 domain is often found in the central cleft of the propeller where the loops connect the successive beta sheets. As both variants are present in those loops (Figure 1D), they may interfere with the protein-protein interaction sites and potentially affect the substrate binding capacity of FZR1 in addition to reducing overall protein stability.

\section{Genetic characterization of fzr alleles in Drosophila}

We decided to examine the functional effect of the DEE-associated variants that we identified using Drosophila as a model organism. For this study we used two EMS (ethylmethanesulfonate)-induced alleles of $f z r\left(f z r^{A}\right.$ and $\left.f z r^{B}\right)$ that we previously isolated. These alleles produce rough eye phenotypes in adult mosaic animals and show defects in electroretinograms ${ }^{22}$, suggesting that $f z r$ is involved in the development and function of the fly visual system. We determined the molecular lesions in these lines using Sanger sequencing of PCR fragments of genomic DNA. The molecular lesions in the $f z r^{A}$ allele is a canonical splicesite mutation (fzr-RA:c.592+1G>A) and the $f z r^{B}$ allele is a missense mutation (fzr-PA:p.G316N, Figure 2A). In the protein structure model, this fly mutation is found close to the p.N333K residue affected in Patient 2 and 3 (Figure 1F).

We created an additional fly mutant by using CRISPR/Cas9 and homology directed repair to introduce an artificial exon containing a splice acceptor-T2A-GAL4-polyA cassette between the first and second exons of Drosophila fzr. This allele is predicted to generate a strong LOF allele that also produces a GAL4 in the same spatial and temporal pattern reflecting the endogenous 
medRxiv preprint doi: https://doi.org/10.1101/2021.06.12.21256778; this version posted June 20, 2021. The copyright holder for this preprint (which was not certified by peer review) is the author/funder, who has granted medRxiv a license to display the preprint in perpetuity. It is made available under a CC-BY-ND 4.0 International license .

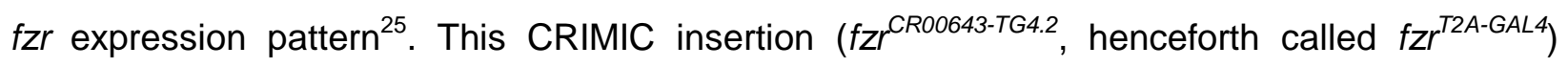
leads to precocious termination of transcription of all $f z r$ isoforms because of the presence of a polyA termination signal as well as an interruption of translation of $f z r$ mRNA due to the viral T2A peptide sequence. T2A also allows re-initiation of translation to express the GAL4 when and where endogenous $f z r$ is expressed (Figure $2 A$ ). The $f z r^{T 2 A-G A L 4}$ allele permits expression of transgenes including $f z r$ cDNA in the native pattern of $f z r$ in the fzr-mutant background by crossing this line to a UAS-fzr transgenic fly (Figure $2 \mathrm{~A})^{25}$, simplifying the functional studies of the variants of interest.

We found that the $f z r^{T 2 A-G A L 4}$ allele is recessive lethal and fails to complement the lethality of a previously reported null allele of $f z r\left(f z r^{j e 28}\right)$, suggesting that $f z r^{T 2 A-G A L 4}$ is a strong LOF allele (Figure 2B). Complementation test between the $f z r^{T 2 A-G A L 4}$ and the EMS-induced mutations $\left(f z r^{A}\right.$ and $f z r^{B}$ ) reaffirmed that these mutations are allelic and are also LOF mutations (Figure 2B). Finally, we examined the rescue of the recessive lethality of $f z r^{T 2 A-G A L 4}$ and the EMS alleles using a duplication containing the fzr locus inserted on the third chromosome $[D p(1 ; 3) D C 472$, Dup]. Each allele was individually rescued by this duplication and the rescued animals did not exhibit any morphological defects, confirming that the phenotypes observed in these alleles are due to LOF of $f z r$ (Figure S3C). To examine the expression pattern of $f z r$ in vivo, we crossed the $f Z r^{T 2 A-G A L 4}$ allele to a UAS-n/s::RFP transgenic line and explored the fluorescent pattern. We found that $f z r$ is broadly expressed in larval brains and eye imaginal discs, consistent with their developmental roles in these tissues (Figure S3D-E).

\section{The role of $f z r$ in neurodevelopment in embryos and larva}

To further characterize the phenotypes of the fzr alleles we generated, we first examined the effect of the Drosophila EMS mutants in developing larval eye imaginal disc and adult retina. We tracked the stereotypical pattern of larval photoreceptor precursors in homozygous mutant cells induced through the expression of eyeless (ey) enhancer driven Flippase ${ }^{57}(e y-F L P)$ that is 
medRxiv preprint doi: https://doi.org/10.1101/2021.06.12.21256778; this version posted June 20, 2021. The copyright holder for this preprint (which was not certified by peer review) is the author/funder, who has granted medRxiv a license to display the preprint in perpetuity. It is made available under a CC-BY-ND 4.0 International license .

generated using the MARCM (Mosaic Analysis with a Repressible Cell Marker) technique ${ }^{60}$. In this experiment, Flippase mediates the recombination of two FRT (Flippase Recognition Target) sites located at the base of the X-chromosome (FRT19A). When this occurs during mitosis and one of the two sister chromatid carries the frz mutant allele, homozygous mutant and homozygous wild-type cells are generated from heterozygous cells (Figure 3A). Simultaneously, it reverses the repression of GAL4 by GAL80 in homozygous mutant cells, allowing the GAL4 to drive the expression of a GFP reporter and simultaneously an optional UAS-fzr cDNA transgene (wt or variant, Figure 3B). Consequently, mutant cells are marked by the GFP reporter and if included, transgenes are expressed within these mutant cells to rescue the phenotype caused by $f z r$ LOF.

In the larval eye disc, the developing photoreceptors were marked by staining for ELAV (Embryonic lethal abnormal vision), a pan-neuronal nuclear marker ${ }^{61}$. In the homozygous mutant cells identified using GFP reporter, we found that the larval photoreceptor patterns marked by ELAV were severely affected (Figure $3 C$ ). This phenotype in the $f z r^{B}$ allele is consistent with previous reports of $f z r$ function in the eye ${ }^{17}$. In adults the pattern of the compound eye was also significantly affected in animals in which mutant mosaic clones were generated (Figure 3D).

To further assess the function of photoreceptors, we performed ERG recordings on 3-4-day old flies. Adult flies with fzr mosaic eyes showed a significant reduction in the depolarization amplitude of the ERG response to light (Figure S2A-B), indicating a defect in phototransduction. These flies also showed severe loss of the ON/OFF transients (Figure S2A-B), suggesting a defect in synaptic transmission.

Next, we examined the embryonic neurogenesis phenotype of the $f z r^{T 2 A-G A L 4}$ mutants by assessing the morphology of the nervous system through immunofluorescence staining and confocal microscopy using an antibody that recognizes neuronal/photoreceptor membranes 
medRxiv preprint doi: https://doi.org/10.1101/2021.06.12.21256778; this version posted June 20, 2021. The copyright holder for this preprint (which was not certified by peer review) is the author/funder, who has granted medRxiv a license to display the preprint in perpetuity. It is made available under a CC-BY-ND 4.0 International license .

(anti-HRP antibody). Hemizygous $f z r^{T 2 A-G A L 4}$ mutant males showed a clear defect in neuronal patterning in the central nervous system of fly embryos, displaying defective neuromere patterns in the ventral nerve chord (Figure S2C). This is consistent with the role of $f z r$ in neuronal development and phenotypes reported for previously identified fzr alleles ${ }^{19}$.

\section{DEE-associated variants fail to support Drosophila neurodevelopment in rescue} experiments in vivo

$f z r^{B}$ mosaic flies showed severe morphological defects in larval eye imaginal discs as evidenced from aberrant anti-HRP staining pattern in the mutant mosaic clones (Figure 3E). We examined the ability of the fzr cDNA with wt sequence or cDNAs with variants corresponding to those of the human patients (Figure $1 \mathrm{~A}$ ) to rescue this phenotype MARCM ${ }^{62}$. We observed that overexpression of the wt fly fzr cDNA in the mutant mosaic clones rescued the HRP pattern defects in the eye discs (Figure 3E-c), but the variant cDNAs failed to display a similar rescue (Figure 3E-d,e).

fzr mutants in Drosophila have also been reported to exhibit defects in glial cell migration ${ }^{17}$. Since glia are known to play important roles in epilepsy ${ }^{63}$, we examined the impact of the two patient variants on this phenotype, again using the MARCM system in the eye imaginal disc. In a control animal (mosaic animals without fzr mutant tissue, Figure 3E-a), glial cells only migrate to areas where photoreceptors have initiated their differentiation program indicated by HRPpositive cells (arrowhead, Figure 3E-a). However, in mosaic cells that are defective for fzr, we observed that glial cells migrate beyond the differentiated zone and prematurely enter areas where immature photoreceptors are present (HRP negative region, Figure 3E-b). We observed that wt $f z r$ cDNA was able to suppress this phenotype (Figure 3E-c) but the fzr cDNAs carrying the patient's variants were not able to rescue the abnormal migration of glial cells (Figure 3Ed,e). This suggests that neuron-glia communication mediated by fzr are also affected by the patient variants. 
medRxiv preprint doi: https://doi.org/10.1101/2021.06.12.21256778; this version posted June 20, 2021. The copyright holder for this preprint (which was not certified by peer review) is the author/funder, who has granted medRxiv a license to display the preprint in perpetuity. It is made available under a CC-BY-ND 4.0 International license .

Since we noticed that overexpression of fzr wild-type cDNA in the eye clones occasionally led to aberrant development patterns, we examined if overexpression of $f z r$ cDNA in wild-type background can disrupt the normal photoreceptor development pattern. Indeed, when wt $f z r$ cDNA was overexpressed in the developing eye using ey-GAL4, we observed a severe reduction in the size of adult retina and loss of photoreceptor pattern (Figure 4B), similar to what has been reported earlier ${ }^{21}$. In this assay, we observed that $f \not r$ cDNA with patient variants also showed caused aberrant photoreceptor patterns (Figure 4C-D). However, the reduction in the size of the adult retina due to the fzr variant overexpression was not as severe as the fzr wt cDNA and the differences between the overexpression of wt and variants were statistically significant (Figure 4E). These results further support that $F Z R 1$ variants associated with DEE are loss of function alleles.

We next examined if wild-type UAS-fzr cDNA can rescue the lethality observed in $f z r^{T 2 A-G A L 4}$ flies. We used GAL4 expressed from the T2A-GAL4 allele to drive the expression of the UAS$f z r$. Expression of wild-type fzr cDNA was able to allow a significant fraction ( 20-23\%) of $f z r^{-T 2 A-}$ ${ }^{G A L 4}$ hemizygous males to live to third instar larval stages whereas they otherwise die as embryo or first instar larvae (Figure 5A). In contrast, the overexpression of fzr cDNA carrying either of the two patient variants fails to rescue this early lethality (Figure 5A). Finally, we examined whether the patient fzr cDNA can rescue the central nervous system development defects in the $f Z r^{T 2 A-G A L 4}$ mutant embryos. The wild-type fzr cDNA was able to restore this defect (Figure 5D), but the two variant cDNAs did not rescue the lesions (Figure 5E-F). Together, the MARCMbased rescue experiments in the developing eye, overexpression analysis in the developing eye, and rescue studies of embryonic neuronal developmental defects all suggest the variants found in three DEE patient act as strong hypomorphic alleles, impacting neuronal development in multiple contexts. 
medRxiv preprint doi: https://doi.org/10.1101/2021.06.12.21256778; this version posted June 20, 2021. The copyright holder for this preprint (which was not certified by peer review) is the author/funder, who has granted medRxiv a license to display the preprint in perpetuity. It is made available under a CC-BY-ND 4.0 International license .

\section{Discussion}

In this study, we describe three individuals with DEE with childhood onset generalized epilepsy carrying a de novo missense variant in FZR1. One missense variant affects the same amino-acid residue as identified in a single previously published patient with $\mathrm{DEE}^{24}$. We further provide statistical and functional support for pathogenicity of these variants.

All four individuals carrying pathogenic de novo FZR1 variants described so far suffer from neurodevelopmental delay and epilepsy. While the previously reported individual had neonatal onset treatment-resistant multifocal seizures, severe ID and prenatal microcephaly ${ }^{24}$, our study shows that the phenotypical spectrum also includes childhood onset generalized seizure syndromes associated with moderate to severe ID, mild ataxia and normal head circumference. This variability could be due to strength of alleles or genetic backgrounds, which will require further investigation. Of note, two patients in our study were diagnosed with MAE. A normal development prior to seizure onset is historically considered a diagnostic criterium for the diagnosis of MAE, but the phenotypic boundaries of this syndrome remain debated ${ }^{64}$. In a recent study on the genetic etiology of MAE, more than $20 \%$ of patients did have developmental delay prior to seizure onset ${ }^{8}$. This feature is indeed inherent to the concept of DEE, which acknowledges that the neurodevelopmental impairment of these patients is not solely related to frequent epileptic activity but is also a direct result of the underlying gene dysfunction. Of note, the $<5$ years-old patient 3 in our study did not have (myoclonic) atonic seizures at time of inclusion in this study. As early disease history is very similar to patient 2 , carrying a variant leading to the same amino-acid substitution, further clinical evolution will tell whether other seizure types will still occur. Both patients also had similar signs of delayed myelination on early brain MRI.

There is a significant enrichment of both de novo and of (predicted) deleterious variants in our patient cohort of DEE patients compared to a control population such as gnomAD. Interestingly, 
medRxiv preprint doi: https://doi.org/10.1101/2021.06.12.21256778; this version posted June 20, 2021. The copyright holder for this preprint (which was not certified by peer review) is the author/funder, who has granted medRxiv a license to display the preprint in perpetuity. It is made available under a CC-BY-ND 4.0 International license .

all four DEE associated variants described so far affect one of two different residues of FZR1. FZR1 variants found in DEE patients affect residues that are likely to be important for the substrate recognition of Cdh1-APC ${ }^{9}$. Variants in this region may lead to altered substrate recognition and therefore lead to a diminished function of Cdh1-APC. Furthermore, we have shown that our patient variants lead to lower protein levels, which could indicate a reduction in the stability of mutant FZR1.

Using our Drosophila functional assays, we show that both p.D187N and p.N333K variants lead to functional deficits in Fzr (Cdh1) protein, especially in the developing nervous system. The DEE-associated variants fail to rescue photoreceptor pattern and glial cell migration that are phenotypes observed in previous $f z r$ alleles in Drosophila and the patient variants behave as partial loss of function alleles. This is also observed in an overexpression assay in the developing eye, as we find that the variants display retention of some function compared to the reference allele. The difference in the functionality between the variants and the wt Fzr is dramatic in the embryonic CNS development as observed using the $f z r^{T 2 A-G A L 4}$ allele, which might provide a more sensitive readout of functional differences. As a regulatory subunit of the E3 ubiquitin ligase complex APC, FZR1 (Cdh1) is involved in the turnover of many substrates ${ }^{65}$. One substrate of Cdh1-APC is FMRP (Fragile X mental Retardation Protein) encoded by the FMR1 (MIM:309550) gene ${ }^{66}$. The interaction of FMRP with Cdh1-APC was shown to regulate metabotropic glutamate receptor (mGluR)-dependent synaptic plasticity ${ }^{66}$ and the formation of stress granules and protein synthesis-dependent synaptic plasticity ${ }^{67}$. Triplet repeat expansion in FMR1 causes Fragile $\mathrm{X}$ syndrome, a neurodevelopmental disorder often accompanied by seizures $^{68}$. HECW2 (HECT, C2 And WW Domain Containing E3 Ubiquitin Protein Ligase 2, also known as NEDL2 MIM:617245) is another substrate of Cdh1-APC ${ }^{69}$ with a link to neurodevelopmental disorders, as de novo missense variants lead to ID, seizures and absent language ${ }^{70}$. Cdh1-APC-mediated degradation of HECW2 during mitotic exit is important for the 
medRxiv preprint doi: https://doi.org/10.1101/2021.06.12.21256778; this version posted June 20, 2021. The copyright holder for this preprint (which was not certified by peer review) is the author/funder, who has granted medRxiv a license to display the preprint in perpetuity. It is made available under a CC-BY-ND 4.0 International license .

regulation of metaphase to anaphase transition ${ }^{69}$. Abnormality of these or other substrates of Cdh1-APC may underlie the DEE and other phenotypes seen in our patients, which will require further molecular studies.

In summary, our work provides genetic, statistical and functional support for the role of $F Z R 1$ in DEE, and we expand the phenotypic spectrum of $F Z R 1$-related encephalopathy to include individuals with DEE with childhood onset generalized epilepsy and normal head circumference. The presence of early neurodevelopmental delay, even prior to seizure onset, is in line with the deleterious impact of patient variants on early neurodevelopment in a Drosophila model. The three molecularly defined $f z r$ alleles $\left(f z r^{A}, f z r^{B}, f z r^{T 2 A-G A L 4}\right)$ are of great value to the study of the role of $f z r$ in Drosophila, and due to the extensive conservation of residues, the study of $F Z R 1$ in human diseases. The fly mutant, overexpression lines, and assays that we have developed in this study will be an important asset for future studies on the role of $F Z R 1$ in neurodevelopment and the impact of human disease variants on its interaction with substrates such as FMRP and HECW2 in the development of DEE.

\section{Supplemental Information}

Supplemental data include three figures and one table.

\section{Declarations of Interests}

The authors declare no competing interests.

\section{Acknowledgements:}

N.S. is supported by the UA-Bijzonder Onderzoeksfonds (BOF)-DOCPRO4 (FFB180186). S.Y. is supported by the following grants from the National Institutes of Health (U54NS093793, R01DC014932, R24OD022005) and through funds provided by the Nancy Chang Ph.D., Award for Research Excellence, Baylor College of Medicine, and the Jan and Dan Duncan 
medRxiv preprint doi: https://doi.org/10.1101/2021.06.12.21256778; this version posted June 20, 2021. The copyright holder for this preprint (which was not certified by peer review) is the author/funder, who has granted medRxiv a license to display the preprint in perpetuity. It is made available under a CC-BY-ND 4.0 International license.

Neurological Research Institute at Texas Children's Hospital. S.W. is supported by the Fonds Wetenschappelijk onderzoek (FWO 1861419N). H.M. is supported by NIH (R01 NS069605). We would like to thank Dr. Michael Wangler for guidance on the bioinformatic analysis of the variants and comments and discussion on the manuscript.

\section{Web resources}

gnomAD https://gnomad.broadinstitute.org/

denovolyzeR https://denovolyzer.org/

Variant Effect Predictor https://www.ensembl.org/info/docs/tools/vep/index.html

OMIM http://www.omim.org/.

PDB https://www.rcsb.org/

\section{Data and Code Availability}

All WES data generated in the EuroEPINOMICS-RES project was deposited in the European Genome-phenome $\quad$ Archive, accession numbers $\quad$ EGAS00001000190, EGAS00001000386, and EGAS00001000048. 
medRxiv preprint doi: https://doi.org/10.1101/2021.06.12.21256778; this version posted June 20, 2021. The copyright holder for this preprint (which was not certified by peer review) is the author/funder, who has granted medRxiv a license to display the preprint in perpetuity. It is made available under a CC-BY-ND 4.0 International license .

\section{References}

1. Scheffer, I.E., Berkovic, S., Capovilla, G., Connolly, M.B., French, J., Guilhoto, L., Hirsch, E., Jain, S., Mathern, G.W., Moshe, S.L., et al. (2017). ILAE classification of the epilepsies: Position paper of the ILAE Commission for Classification and Terminology. Epilepsia 58, 512-521.

2. Truty, R., Patil, N., Sankar, R., Sullivan, J., Millichap, J., Carvill, G., Entezam, A., Esplin, E.D., Fuller, A., Hogue, M., et al. (2019). Possible precision medicine implications from genetic testing using combined detection of sequence and intragenic copy number variants in a large cohort with childhood epilepsy. Epilepsia open 4, 397-408.

3. McTague, A., Howell, K.B., Cross, J.H., Kurian, M.A., and Scheffer, I.E. (2016). The genetic landscape of the epileptic encephalopathies of infancy and childhood. The Lancet Neurology 15, 304-316.

4. Thomas, R.H., and Berkovic, S.F. (2014). The hidden genetics of epilepsy-a clinically important new paradigm. Nature reviews Neurology 10, 283-292.

5. Snoeijen-Schouwenaars, F.M., van Ool, J.S., Verhoeven, J.S., van Mierlo, P., Braakman, H.M.H., Smeets, E.E., Nicolai, J., Schoots, J., Teunissen, M.W.A., Rouhl, R.P.W., et al. (2019). Diagnostic exome sequencing in 100 consecutive patients with both epilepsy and intellectual disability. Epilepsia 60, 155-164.

6. Demos, M., Guella, I., DeGuzman, C., McKenzie, M.B., Buerki, S.E., Evans, D.M., Toyota, E.B., Boelman, C., Huh, L.L., Datta, A., et al. (2019). Diagnostic Yield and Treatment Impact of Targeted Exome Sequencing in Early-Onset Epilepsy. Frontiers in neurology 10, 434.

7. Larsen, J., Johannesen, K.M., Ek, J., Tang, S., Marini, C., Blichfeldt, S., Kibaek, M., von Spiczak, S., Weckhuysen, S., Frangu, M., et al. (2015). The role of SLC2A1 mutations in myoclonic astatic epilepsy and absence epilepsy, and the estimated frequency of GLUT1 deficiency syndrome. Epilepsia 56, e203-208.

8. Tang, S., Addis, L., Smith, A., Topp, S.D., Pendziwiat, M., Mei, D., Parker, A., Agrawal, S., Hughes, E., Lascelles, K., et al. (2020). Phenotypic and genetic spectrum of epilepsy with myoclonic atonic seizures. Epilepsia 61, 995-1007.

9. Chang, L.F., Zhang, Z., Yang, J., McLaughlin, S.H., and Barford, D. (2014). Molecular architecture and mechanism of the anaphase-promoting complex. Nature 513, 388-393.

10. Fang, G., Yu, H., and Kirschner, M.W. (1998). Direct binding of CDC20 protein family members activates the anaphase-promoting complex in mitosis and G1. Molecular cell 2, 163-171.

11. Sudo, T., Ota, Y., Kotani, S., Nakao, M., Takami, Y., Takeda, S., and Saya, H. (2001). Activation of Cdh1-dependent APC is required for G1 cell cycle arrest and DNA damage-induced G2 checkpoint in vertebrate cells. The EMBO journal 20, 6499-6508.

12. García-Higuera, I., Manchado, E., Dubus, P., Cañamero, M., Méndez, J., Moreno, S., and Malumbres, M. (2008). Genomic stability and tumour suppression by the APC/C cofactor $C d h 1$. Nature cell biology 10, 802-811.

13. Delgado-Esteban, M., Garcia-Higuera, I., Maestre, C., Moreno, S., and Almeida, A. (2013). APC/CCdh1 coordinates neurogenesis and cortical size during development. Nature communications 4 , 2879.

14. Huang, J., and Bonni, A. (2016). A decade of the anaphase-promoting complex in the nervous system. Genes \& development 30, 622-638.

15. Li, J., Chen, X., Li, X., Hu, R., Yao, W., Mei, W., Wan, L., Gui, L., and Zhang, C. (2020). Upregulation of Cdh1 in the trigeminal spinal subnucleus caudalis attenuates trigeminal neuropathic pain via inhibiting GABAergic neuronal apoptosis. Neurochemistry international 133, 104613.

16. Li, Z., Zhang, B., Yao, W., Zhang, C., Wan, L., and Zhang, Y. (2019). APC-Cdh1 Regulates Neuronal Apoptosis Through Modulating Glycolysis and Pentose-Phosphate Pathway After OxygenGlucose Deprivation and Reperfusion. Cellular and molecular neurobiology 39, 123-135. 
medRxiv preprint doi: https://doi.org/10.1101/2021.06.12.21256778; this version posted June 20, 2021. The copyright holder for this preprint (which was not certified by peer review) is the author/funder, who has granted medRxiv a license to display the preprint in perpetuity. It is made available under a CC-BY-ND 4.0 International license .

17. Neuert, H., Yuva-Aydemir, Y., Silies, M., and Klambt, C. (2017). Different modes of APC/C activation control growth and neuron-glia interaction in the developing Drosophila eye. Development 144, 4673-4683.

18. Bobo-Jimenez, V., Delgado-Esteban, M., Angibaud, J., Sanchez-Moran, I., de la Fuente, A., Yajeya, J., Nagerl, U.V., Castillo, J., Bolanos, J.P., and Almeida, A. (2017). APC/C(Cdh1)-Rock2 pathway controls dendritic integrity and memory. Proceedings of the National Academy of Sciences of the United States of America 114, 4513-4518.

19. Silies, M., and Klambt, C. (2010). APC/C(Fzr/Cdh1)-dependent regulation of cell adhesion controls glial migration in the Drosophila PNS. Nat Neurosci 13, 1357-1364.

20. Sigrist, S.J., and Lehner, C.F. (1997). Drosophila fizzy-related down-regulates mitotic cyclins and is required for cell proliferation arrest and entry into endocycles. Cell 90, 671-681.

21. Pimentel, A.C., and Venkatesh, T.R. (2005). rap gene encodes Fizzy-related protein (Fzr) and regulates cell proliferation and pattern formation in the developing Drosophila eye-antennal disc. Developmental biology 285, 436-446.

22. Yamamoto, S., Jaiswal, M., Charng, W.L., Gambin, T., Karaca, E., Mirzaa, G., Wiszniewski, W., Sandoval, H., Haelterman, N.A., Xiong, B., et al. (2014). A drosophila genetic resource of mutants to study mechanisms underlying human genetic diseases. Cell 159, 200-214.

23. Karpilow, J., Kolodkin, A., Bork, T., and Venkatesh, T. (1989). Neuronal development in the Drosophila compound eye: rap gene function is required in photoreceptor cell R8 for ommatidial pattern formation. Genes \& development 3, 1834-1844.

24. Rodriguez, C., Sanchez-Moran, I., Alvarez, S., Tirado, P., Fernandez-Mayoralas, D.M., Calleja-Perez, B., Almeida, A., and Fernandez-Jaen, A. (2019). A novel human Cdh1 mutation impairs anaphase promoting complex/cyclosome activity resulting in microcephaly, psychomotor retardation, and epilepsy. Journal of neurochemistry 151, 103-115.

25. Barbosa, M., Joshi, R.S., Garg, P., Martin-Trujillo, A., Patel, N., Jadhav, B., Watson, C.T., Gibson, W., Chetnik, K., Tessereau, C., et al. (2018). Identification of rare de novo epigenetic variations in congenital disorders. Nature communications 9, 2064.

26. Suls, A., Jaehn, J.A., Kecskes, A., Weber, Y., Weckhuysen, S., Craiu, D.C., Siekierska, A., Djemie, T., Afrikanova, T., Gormley, P., et al. (2013). De novo loss-of-function mutations in CHD2 cause a fever-sensitive myoclonic epileptic encephalopathy sharing features with Dravet syndrome. Am J Hum Genet 93, 967-975.

27. Reumers, J., De Rijk, P., Zhao, H., Liekens, A., Smeets, D., Cleary, J., Van Loo, P., Van Den Bossche, M., Catthoor, K., Sabbe, B., et al. (2011). Optimized filtering reduces the error rate in detecting genomic variants by short-read sequencing. Nature biotechnology 30, 61-68.

28. Lek, M., Karczewski, K.J., Minikel, E.V., Samocha, K.E., Banks, E., Fennell, T., O'Donnell-Luria, A.H., Ware, J.S., Hill, A.J., Cummings, B.B., et al. (2016). Analysis of protein-coding genetic variation in 60,706 humans. Nature 536, 285-291.

29. Karczewski, K.J., Francioli, L.C., Tiao, G., Cummings, B.B., Alfoldi, J., Wang, Q., Collins, R.L., Laricchia, K.M., Ganna, A., Birnbaum, D.P., et al. (2020). The mutational constraint spectrum quantified from variation in 141,456 humans. Nature 581, 434-443.

30. (2015). Human genomics. The Genotype-Tissue Expression (GTEx) pilot analysis: multitissue gene regulation in humans. Science (New York, NY) 348, 648-660.

31. Rentzsch, P., Witten, D., Cooper, G.M., Shendure, J., and Kircher, M. (2019). CADD: predicting the deleteriousness of variants throughout the human genome. Nucleic acids research 47, D886d894.

32. Carvill, G.L., McMahon, J.M., Schneider, A., Zemel, M., Myers, C.T., Saykally, J., Nguyen, J., Robbiano, A., Zara, F., Specchio, N., et al. (2015). Mutations in the GABA Transporter SLC6A1 Cause Epilepsy with Myoclonic-Atonic Seizures. Am J Hum Genet 96, 808-815. 
medRxiv preprint doi: https://doi.org/10.1101/2021.06.12.21256778; this version posted June 20, 2021. The copyright holder for this preprint (which was not certified by peer review) is the author/funder, who has granted medRxiv a license to display the preprint in perpetuity. It is made available under a CC-BY-ND 4.0 International license .

33. Sobreira, N., Schiettecatte, F., Valle, D., and Hamosh, A. (2015). GeneMatcher: a matching tool for connecting investigators with an interest in the same gene. Human mutation 36, 928-930.

34. Kumar, P., Henikoff, S., and Ng, P.C. (2009). Predicting the effects of coding non-synonymous variants on protein function using the SIFT algorithm. Nature protocols 4, 1073-1081.

35. Adzhubei, I.A., Schmidt, S., Peshkin, L., Ramensky, V.E., Gerasimova, A., Bork, P., Kondrashov, A.S., and Sunyaev, S.R. (2010). A method and server for predicting damaging missense mutations. Nature methods 7, 248-249.

36. Ware, J.S., Samocha, K.E., Homsy, J., and Daly, M.J. (2015). Interpreting de novo Variation in Human Disease Using denovolyzeR. Current protocols in human genetics 87, 7.25.21-27.25.15.

37. McLaren, W., Gil, L., Hunt, S.E., Riat, H.S., Ritchie, G.R., Thormann, A., Flicek, P., and Cunningham, F. (2016). The Ensembl Variant Effect Predictor. Genome biology 17, 122.

38. Haelterman, N.A., Jiang, L., Li, Y., Bayat, V., Sandoval, H., Ugur, B., Tan, K.L., Zhang, K., Bei, D., Xiong, B., et al. (2014). Large-scale identification of chemically induced mutations in Drosophila melanogaster. Genome research 24, 1707-1718.

39. Nagarkar-Jaiswal, S., Manivannan, S.N., Zuo, Z., and Bellen, H.J. (2017). A cell cycle-independent, conditional gene inactivation strategy for differentially tagging wild-type and mutant cells. Elife 6.

40. Venken, K.J., He, Y., Hoskins, R.A., and Bellen, H.J. (2006). P[acman]: a BAC transgenic platform for targeted insertion of large DNA fragments in D. melanogaster. Science (New York, NY) 314, 1747-1751.

41. Venken, K.J., Carlson, J.W., Schulze, K.L., Pan, H., He, Y., Spokony, R., Wan, K.H., Koriabine, M., de Jong, P.J., White, K.P., et al. (2009). Versatile P[acman] BAC libraries for transgenesis studies in Drosophila melanogaster. Nature methods 6, 431-434.

42. Venken, K.J., Popodi, E., Holtzman, S.L., Schulze, K.L., Park, S., Carlson, J.W., Hoskins, R.A., Bellen, H.J., and Kaufman, T.C. (2010). A molecularly defined duplication set for the $X$ chromosome of Drosophila melanogaster. Genetics 186, 1111-1125.

43. Harnish, J.M., Deal, S.L., Chao, H.T., Wangler, M.F., and Yamamoto, S. (2019). In Vivo Functional Study of Disease-associated Rare Human Variants Using Drosophila. Journal of visualized experiments : JoVE.

44. Wu, J.S., and Luo, L. (2006). A protocol for mosaic analysis with a repressible cell marker (MARCM) in Drosophila. Nature protocols 1, 2583-2589.

45. Bellen, H.J., Wangler, M.F., and Yamamoto, S. (2019). The fruit fly at the interface of diagnosis and pathogenic mechanisms of rare and common human diseases. Human molecular genetics 28 , R207-r214.

46. Alfonso, T.B., and Jones, B.W. (2002). gcm2 promotes glial cell differentiation and is required with glial cells missing for macrophage development in Drosophila. Developmental biology 248, 369383.

47. O'Neill, E.M., Rebay, I., Tjian, R., and Rubin, G.M. (1994). The activities of two Ets-related transcription factors required for Drosophila eye development are modulated by the Ras/MAPK pathway. Cell 78, 137-147.

48. Schindelin, J., Arganda-Carreras, I., Frise, E., Kaynig, V., Longair, M., Pietzsch, T., Preibisch, S., Rueden, C., Saalfeld, S., Schmid, B., et al. (2012). Fiji: an open-source platform for biologicalimage analysis. Nature methods 9, 676-682.

49. Manivannan, S.N., Darouich, S., Masmoudi, A., Gordon, D., Zender, G., Han, Z., Fitzgerald-Butt, S., White, P., McBride, K.L., Kharrat, M., et al. (2020). Novel frameshift variant in MYL2 reveals molecular differences between dominant and recessive forms of hypertrophic cardiomyopathy. PLoS Genet 16, e1008639. 
medRxiv preprint doi: https://doi.org/10.1101/2021.06.12.21256778; this version posted June 20, 2021. The copyright holder for this preprint

(which was not certified by peer review) is the author/funder, who has granted medRxiv a license to display the preprint in perpetuity.

It is made available under a CC-BY-ND 4.0 International license .

50. Lee, H.S., Kim, M.W., Jin, K.S., Shin, H.C., Kim, W.K., Lee, S.C., Kim, S.J., Lee, E.W., and Ku, B. (2021). Molecular Analysis of the Interaction between Human PTPN21 and the Oncoprotein E7 from Human Papillomavirus Genotype 18. Molecules and cells 44, 26-37.

51. Campbell, J.S., Davidson, A.J., Todd, H., Rodrigues, F., Elliot, A.M., Early, J.J., Lyons, D.A., Feng, Y., and Wood, W. (2021). PTPN21/Pez Is a Novel and Evolutionarily Conserved Key Regulator of Inflammation In Vivo. Current biology : CB 31, 875-883.e875.

52. Chen, J., Lee, G., Fanous, A.H., Zhao, Z., Jia, P., O'Neill, A., Walsh, D., Kendler, K.S., and Chen, X. (2011). Two non-synonymous markers in PTPN21, identified by genome-wide association study data-mining and replication, are associated with schizophrenia. Schizophrenia research 131, 4351.

53. Siddiqui, N., Zwetsloot, A.J., Bachmann, A., Roth, D., Hussain, H., Brandt, J., Kaverina, I., and Straube, A. (2019). PTPN21 and Hook3 relieve KIF1C autoinhibition and activate intracellular transport. Nature communications 10, 2693.

54. Plani-Lam, J.H., Chow, T.C., Siu, K.L., Chau, W.H., Ng, M.H., Bao, S., Ng, C.T., Sham, P., Shum, D.K., Ingley, E., et al. (2015). PTPN21 exerts pro-neuronal survival and neuritic elongation via ErbB4/NRG3 signaling. The international journal of biochemistry \& cell biology 61, 53-62.

55. Larocque, G., La-Borde, P.J., Clarke, N.I., Carter, N.J., and Royle, S.J. (2020). Tumor protein D54 defines a new class of intracellular transport vesicles. The Journal of cell biology 219.

56. Mukudai, Y., Kondo, S., Fujita, A., Yoshihama, Y., Shirota, T., and Shintani, S. (2013). Tumor protein D54 is a negative regulator of extracellular matrix-dependent migration and attachment in oral squamous cell carcinoma-derived cell lines. Cellular oncology (Dordrecht) 36, 233-245.

57. Newsome, T.P., Asling, B., and Dickson, B.J. (2000). Analysis of Drosophila photoreceptor axon guidance in eye-specific mosaics. Development 127, 851-860.

58. Stirnimann, C.U., Petsalaki, E., Russell, R.B., and Muller, C.W. (2010). WD40 proteins propel cellular networks. Trends Biochem Sci 35, 565-574.

59. Kanca, O., Andrews, J.C., Lee, P.T., Patel, C., Braddock, S.R., Slavotinek, A.M., Cohen, J.S., Gubbels, C.S., Aldinger, K.A., Williams, J., et al. (2019). De Novo Variants in WDR37 Are Associated with Epilepsy, Colobomas, Dysmorphism, Developmental Delay, Intellectual Disability, and Cerebellar Hypoplasia. Am J Hum Genet 105, 413-424.

60. Lee, T., and Luo, L. (2001). Mosaic analysis with a repressible cell marker (MARCM) for Drosophila neural development. Trends Neurosci 24, 251-254.

61. Yao, K.M., Samson, M.L., Reeves, R., and White, K. (1993). Gene elav of Drosophila melanogaster: a prototype for neuronal-specific RNA binding protein gene family that is conserved in flies and humans. J Neurobiol 24, 723-739.

62. Lee, T., and Luo, L. (1999). Mosaic analysis with a repressible cell marker for studies of gene function in neuronal morphogenesis. Neuron 22, 451-461.

63. Heuser, K., Szokol, K., and Taubøll, E. (2014). The role of glial cells in epilepsy. Tidsskrift for den Norske laegeforening : tidsskrift for praktisk medicin, ny raekke 134, 37-41.

64. Nickels, K. (2020). Epilepsy With Myoclonic Atonic Seizures: Why Is the Yield of Genetic Testing for a "Presumed Genetic" Epilepsy Low? Epilepsy Currents 20, 351-352.

65. Zhou, Z., He, M., Shah, A.A., and Wan, Y. (2016). Insights into APC/C: from cellular function to diseases and therapeutics. Cell division 11, 9.

66. Huang, J., Ikeuchi, Y., Malumbres, M., and Bonni, A. (2015). A Cdh1-APC/FMRP Ubiquitin Signaling Link Drives mGluR-Dependent Synaptic Plasticity in the Mammalian Brain. Neuron 86, 726-739.

67. Valdez-Sinon, A.N., Lai, A., Shi, L., Lancaster, C.L., Gokhale, A., Faundez, V., and Bassell, G.J. (2020). Cdh1-APC Regulates Protein Synthesis and Stress Granules in Neurons through an FMRPDependent Mechanism. iScience 23, 101132. 
medRxiv preprint doi: https://doi.org/10.1101/2021.06.12.21256778; this version posted June 20, 2021. The copyright holder for this preprint (which was not certified by peer review) is the author/funder, who has granted medRxiv a license to display the preprint in perpetuity. It is made available under a CC-BY-ND 4.0 International license.

68. Verkerk, A.J., Pieretti, M., Sutcliffe, J.S., Fu, Y.H., Kuhl, D.P., Pizzuti, A., Reiner, O., Richards, S., Victoria, M.F., Zhang, F.P., et al. (1991). Identification of a gene (FMR-1) containing a CGG repeat coincident with a breakpoint cluster region exhibiting length variation in fragile $\mathrm{X}$ syndrome. Cell 65, 905-914.

69. Lu, L., Hu, S., Wei, R., Qiu, X., Lu, K., Fu, Y., Li, H., Xing, G., Li, D., Peng, R., et al. (2013). The HECT type ubiquitin ligase NEDL2 is degraded by anaphase-promoting complex/cyclosome (APC/C)-Cdh1, and its tight regulation maintains the metaphase to anaphase transition. The Journal of biological chemistry 288, 35637-35650.

70. Berko, E.R., Cho, M.T., Eng, C., Shao, Y., Sweetser, D.A., Waxler, J., Robin, N.H., Brewer, F., Donkervoort, S., Mohassel, P., et al. (2017). De novo missense variants in HECW2 are associated with neurodevelopmental delay and hypotonia. Journal of medical genetics 54, 84-86. 
medRxiv preprint doi: https://doi.org/10.1101/2021.06.12.21256778; this version posted June 20, 2021. The copyright holder for this preprint (which was not certified by peer review) is the author/funder, who has granted medRxiv a license to display the preprint in perpetuity.

It is made available under a CC-BY-ND 4.0 International license .

\section{Figure legends}

Figure 1. Conservation FZR1 and in vitro analysis of DEE variants in mammalian cells. (A)

Protein primary structure diagram of human FZR1 and Drosophila ortholog Fzr showing conserved domains and corresponding positions of variants observed in patients. The residues affected in the patients are conserved in Drosophila melanogaster. Amino acid sequence alignment of human FZR1 and Drosophila Fzr region encompassing the DEE variant residues which shown in red boxes. (B) Immunofluorescence staining for eGFP tagged human FZR1 cDNA in HEK293 cells (green), co-stained with DAPI (nucleus; blue) and actin-cytoskeleton (Phalloidin; magenta). (a-b) FZR1-wt, (c-d) FZR1:p.D187N, (e-f) FZR1:p.N333K localization to the nucleus and the cytoplasm. (C) Western blot showing relative expression of FZR1-wt and variants in HEK-293 cells. Alpha-tubulin is used as loading control. (D) Quantitation of normalized western blot signal analyzed using one-way ANOVA, followed by Dunnett test for comparison of the variants to the wt expression. ${ }^{* *}$ indicates multiplicity adjusted P-value $<0.01$. (E) 3D structural model FZR1 as part of the Cdh1-APC (PDB:4ui9) ${ }^{9}$ showing the relative positions of the variants affected in the DEE patients (green) and corresponding residue of the Drosophila mutation observed in the $f z r^{B}$ allele (blue). 
medRxiv preprint doi: https://doi.org/10.1101/2021.06.12.21256778; this version posted June 20, 2021. The copyright holder for this preprint (which was not certified by peer review) is the author/funder, who has granted medRxiv a license to display the preprint in perpetuity. It is made available under a CC-BY-ND 4.0 International license .

Figure 2. Drosophila fzr alleles and expression pattern. (A) Drosophila $X$-chromosome locus showing two transcriptional isoforms of $f z r$, two EMS-induced mutation alleles $f z r^{A}$ (splice-site mutation) and $f z r^{B}$ (missense mutation located in the same domain as one of the patient's variants), $f z r^{j e 28}$ (deletion spanning the first two exons of $f z r$ ) and a third chromosome duplication allele carrying a complete copy of fzr from the $X$-chromosome. Also shown is the fzr ${ }^{T 2 A-G A L 4}$ allele generated by insertion of a mutagenic T2A-GAL4 artificial exon within the second intron of $f z r$. This insertion leads to termination of $f z r$ translation and expression of GAL4 protein from the endogenous fzr locus. (C) Table showing results of complementation tests between various alleles of $f z r$ as well the $f z r$ locus duplication shown in (B). (C-D) Expression pattern of fzr in Drosophila third instar visualized using the $f z r^{T 2 A-G A L 4}$ driving the expression of $n / s:: R F P$ (red) costained with ELAV marking neuronal cells (green) and DAPI to detect nucleus (blue). (C) Larval brain and higher magnification images of the boxed region. (D) The eye-antennal disc and higher magnification images of the boxed region. 
medRxiv preprint doi: https://doi.org/10.1101/2021.06.12.21256778; this version posted June 20, 2021. The copyright holder for this preprint (which was not certified by peer review) is the author/funder, who has granted medRxiv a license to display the preprint in perpetuity. It is made available under a CC-BY-ND 4.0 International license .

Figure 3. Pattern formation and glial migration defects in the photoreceptor precursors of fzr mutants are not rescued by DEE variants. (A) Diagram showing the generation of random mosaic patches of homozygous fzr mutant cells in the developing eye disc that are marked by GFP expression using MARCM. (B) Schematic diagram showing gene expression differences between homozygous fzr mutant (GFP+) cells and the surrounding heterozygous $f z r$ (GFP-) cells. In mutant cells, Actin5c-GAL4 drives the expression of GFP and fzr cDNA (wild-type or patient variant), while in heterozygous cells, GAL4 activity is suppressed by GAL80. (C a-d) Control larval eye discs showing expression pattern of ELAV (red) in mosaics marked by GFP expression generated using MARCM. (C e-h) larval eye disc showing mosaic homozygous $f z r^{B}$ tissue (green) showing dramatic change in ELAV (magenta) expression within and outside the clones, showing cell autonomous and non-autonomous effect of $f z r$ loss in vivo. (D-a) Control adult eye showing stereotypical pattern of compound eye. (D-b) Aberrant retina pattern observed in $f z r^{\beta}$ mosaic adults. (E) MARCM mosaics generated as above stained with HRP (photoreceptor membrane). Magnified regions showing HRP boundary in dotted lines and glial cells stained with ani-Repo antibody. (E-a) Control larval eye imaginal disc showing limitation of glial cells to the boundary set by HRP positive cells (boundary traced by white dotted lines). (Eb) $f z r^{\beta}$ mosaics showing not only disturbances in HRP pattern but also migration of glial cells past the boundaries (arrowhead) of HRP positive cells. (E-c) Eye imaginal discs showing rescue of HRP pattern and glial cell migration when fzr wild-type cDNA is overexpressed in mutant mosaics. (E-d) Eye imaginal discs showing glial migration in regions lacking HRP signal when fzr cDNA with variant p.D172N is overexpressed in fzr mutant cells. (E-e) Eye imaginal discs showing similar defects in glial cell migration when fzr cDNA with variant p.N318K is expressed in fzr mutant cells. 
medRxiv preprint doi: https://doi.org/10.1101/2021.06.12.21256778; this version posted June 20, 2021. The copyright holder for this preprint (which was not certified by peer review) is the author/funder, who has granted medRxiv a license to display the preprint in perpetuity.

Figure 4. Overexpression of fzr leads to aberrant retinas. (A) Control ey3.5-GAL4 eyes showing stereotypical photoreceptor pattern and retina size. (B) eyes of animals with wild-type fzr overexpressed using ey3.5-GAL4 showing severe eye size reduction and disrupted ommatidia pattern. (C) Adult eyes of ey3.5-GAL4 mediated overexpression of Fzr:p.D172N leading loss of photoreceptor pattern and reduction in retina size. (D) Adult eyes ey3.5-GAL4 mediated overexpression of Fzr:p.N318K leading to disruption in ommatidia pattern and reduction in eye size. (E) Quantitation of the eye size shows significant reduction of retina area due to the overexpression of wild-type or variant fzr cDNAs. Reduction in the eye size due to variant overexpression is not as severe as defects caused by wild-type Fzr and are statistically significant. Statistical difference evaluated using one-way ANOVA between all the samples followed by pair-wise analysis using Tukey's multiple comparison. (multiplicity corrected P-value indicated as $\left.{ }^{* * *}<0.0001,{ }^{* *}<0.001,{ }^{*}<0.05\right)$. 
medRxiv preprint doi: https://doi.org/10.1101/2021.06.12.21256778; this version posted June 20, 2021. The copyright holder for this preprint (which was not certified by peer review) is the author/funder, who has granted medRxiv a license to display the preprint in perpetuity.

Figure 5. Embryonic central nervous system defects in $f z r^{T 2 A-G A L 4}$ mutants are not rescued by Fzr carrying DEE patient variants. (A) Diagram showing the crossing scheme used to assess rescue of lethality observed in $f z r^{T 2 A-G A L 4}$ using overexpression of wt or variant Drosophila Fzr and bar plots showing percentage of later third instar (L3) male larvae recovered by the overexpression of wild-type and variant cDNAs in a $f z r^{T 2 A-G A L 4}$ mutant background. (B-F) Drosophila embryos at stage 15-16 showing neuronal membranes stained with HRP. (A) fzr ${ }^{T 2 A}$ ${ }^{G A L 4}$ hemizygous embryo $\left(f z r^{T 2 A-G A L 4} / Y\right.$ ) rescued with duplication of $f z r$ genomic region on third chromosome serving as control. (B) $f z r^{T 2 A-G A L 4} / Y$ embrryos showing severe defects in the patten of neuron development. (C) Wild-type Fzr expression using the $f z r^{T 2 A-G A L 4}$ rescues neuronal pattern. (D-E) $f z r^{T 2 A-G A L 4}$ shows neurodevelopmental defects that are not rescued by the expression of Fzr p.D172N or p.N318K. 
medRxiv preprint doi: https://doi.org/10.1101/2021.06.12.21256778; this version posted June 20, 2021. The copyright holder for this preprint (which was not certified by peer review) is the author/funder, who has granted medRxiv a license to display the preprint in perpetuity.

It is made available under a CC-BY-ND 4.0 International license .

Table 1. Clinical features.

\begin{tabular}{|c|c|c|c|c|}
\hline & Patient 1 & Patient 2 & Patient 3 & Rodriguez et al. ${ }^{24}$ \\
\hline Sex & $\mathrm{M}$ & $\mathrm{F}$ & $\mathrm{F}$ & $\mathrm{M}$ \\
\hline Age at study & $11-20$ years & $11-20$ years & $2-5$ years & $2-5$ years \\
\hline $\begin{array}{l}\text { FZR1 variant ( } \\
\text { NC_000019.9, } \\
\text { NM_016263.3) }\end{array}$ & $\begin{array}{l}\text { g.3527717G }>A \\
\text { c.559G }>A \text {, } \\
\text { p. }(D 187 N)\end{array}$ & $\begin{array}{l}\text { g.3532084C>G } \\
\text { c.999C>G, } \\
\text { p. }(\text { N333K) }\end{array}$ & $\begin{array}{l}\text { g.3532084C>A } \\
\text { c. } 999 \mathrm{C}>\mathrm{A}, \\
\text { p. }(\mathrm{N} 333 \mathrm{~K})\end{array}$ & $\begin{array}{l}\text { g.3527718A>G } \\
\text { c.560A>G, } \\
\text { p.(D187G) }\end{array}$ \\
\hline Inheritance & De novo & De novo & De novo & De novo \\
\hline $\begin{array}{l}\text { Development } \\
\text { prior to seizure } \\
\text { onset }\end{array}$ & $\begin{array}{l}\text { Delayed } \\
\text { language } \\
\text { development, } \\
\text { fine motor } \\
\text { problems }\end{array}$ & $\begin{array}{l}\text { Delayed } \\
\text { language } \\
\text { development, } \\
\text { instable gait }\end{array}$ & $\begin{array}{l}\text { Delayed motor } \\
\text { and language } \\
\text { development }\end{array}$ & NA (neonatal sz) \\
\hline $\begin{array}{l}\text { Age at seizure } \\
\text { onset }\end{array}$ & $2-5$ years & $2-5$ years & $2-5$ years & $<1$ year \\
\hline $\begin{array}{l}\text { Type(s) of } \\
\text { seizure at onset }\end{array}$ & $\begin{array}{l}\text { Generalized } \\
\text { tonic clonic sz }\end{array}$ & $\begin{array}{l}\text { Generalized } \\
\text { tonic clonic sz }\end{array}$ & $\begin{array}{l}\text { Generalized } \\
\text { tonic clonic sz }\end{array}$ & $\begin{array}{l}\text { Right hemiclonic } \\
\text { sz }\end{array}$ \\
\hline $\begin{array}{l}\text { Additional } \\
\text { seizure types }\end{array}$ & $\begin{array}{l}\text { Myoclonic, } \\
\text { atonic, absences }\end{array}$ & $\begin{array}{l}\text { Myoclonic, tonic, } \\
\text { atonic, atypical } \\
\text { absences }\end{array}$ & $\begin{array}{l}\text { Myoclonic, } \\
\text { atypical } \\
\text { absences }\end{array}$ & $\begin{array}{l}\text { Right and left } \\
\text { hemiclonic, left } \\
\text { focal, generalized } \\
\text { tonic-clonic, } \\
\text { versive }\end{array}$ \\
\hline EEG at onset & $\begin{array}{l}\text { Slow } \\
\text { background, } \\
\text { generalized } \\
\text { epileptic activity }\end{array}$ & $\begin{array}{l}\text { Slow } \\
\text { background, } \\
\text { burst of high } \\
\text { voltage slow } \\
\text { waves }\end{array}$ & $\begin{array}{l}\text { Generalized } \\
\text { spike wave } \\
\text { complexes }\end{array}$ & NA \\
\hline $\begin{array}{l}\text { Intellectual } \\
\text { Disability }\end{array}$ & Moderate & Severe & Severe & Severe \\
\hline $\begin{array}{l}\text { Behavioral } \\
\text { problems }\end{array}$ & $\begin{array}{l}\text { Hyperactivity } \\
\text { and attention } \\
\text { problems }\end{array}$ & $\begin{array}{l}\text { ASD, attention } \\
\text { problems }\end{array}$ & No & NA \\
\hline Brain MRI & Normal & $\begin{array}{l}\text { Aspecific } \\
\text { parieto-occipital } \\
\text { white matter } \\
\text { hyperintensities } \\
\text { (2-5 years) }\end{array}$ & $\begin{array}{l}\text { Mild } \\
\text { frontotemporal } \\
\text { accentuated } \\
\text { volume } \\
\text { reduction; flair } \\
\text { hyperintense } \\
\text { signal alterations } \\
\text { paratrigonal to } \\
\text { frontoparietal } \\
\text { (3y) }\end{array}$ & $\begin{array}{l}\text { Microcephaly, } \\
\text { further normal }\end{array}$ \\
\hline $\begin{array}{l}\text { Head } \\
\text { circumference } \\
\text { [percentile] }\end{array}$ & 23th & 4th & 42th & $<3 r d$ \\
\hline $\begin{array}{l}\text { Neurological } \\
\text { exam }\end{array}$ & $\begin{array}{l}\text { Mild ataxic gait } \\
\text { and some } \\
\text { orofacial } \\
\text { coordination }\end{array}$ & $\begin{array}{l}\text { Moderate crouch } \\
\text { gait, lumbar } \\
\text { hyperlordosis, } \\
\text { hyporeflexia, }\end{array}$ & $\begin{array}{l}\text { Muscular } \\
\text { hypotonia, } \\
\text { coordination } \\
\text { problems, mild }\end{array}$ & $\begin{array}{l}\text { Severe axial } \\
\text { hypotonia, } \\
\text { exaggerated } \\
\text { deep-tendon }\end{array}$ \\
\hline
\end{tabular}


medRxiv preprint doi: https://doi.org/10.1101/2021.06.12.21256778; this version posted June 20, 2021. The copyright holder for this preprint (which was not certified by peer review) is the author/funder, who has granted medRxiv a license to display the preprint in perpetuity.

It is made available under a CC-BY-ND 4.0 International license .

\begin{tabular}{|l|l|l|l|l|}
\hline & problems & mild ataxic gait & ataxic gait & $\begin{array}{l}\text { reflexes, } \\
\text { spasticity }\end{array}$ \\
\hline Other features & No & No & $\begin{array}{l}\text { Dysmorphic } \\
\text { features: Deep } \\
\text { set eyes, high } \\
\text { nalas bridge, } \\
\text { broad nasal tip } \\
\text { Low set ears. } \\
\text { Sleep } \\
\text { ultrasound: mild } \\
\text { mitral and } \\
\text { tricuspid } \\
\text { insufficiency and }\end{array}$ & $\begin{array}{l}\text { left ventricular } \\
\text { hypertrophy }\end{array}$ \\
& & & & \\
& & & \\
\hline
\end{tabular}

Abbreviations used: EEG: electroencephalogram, m: months, NA: not applicable, sz: seizures,

y: years. 
Figure 1

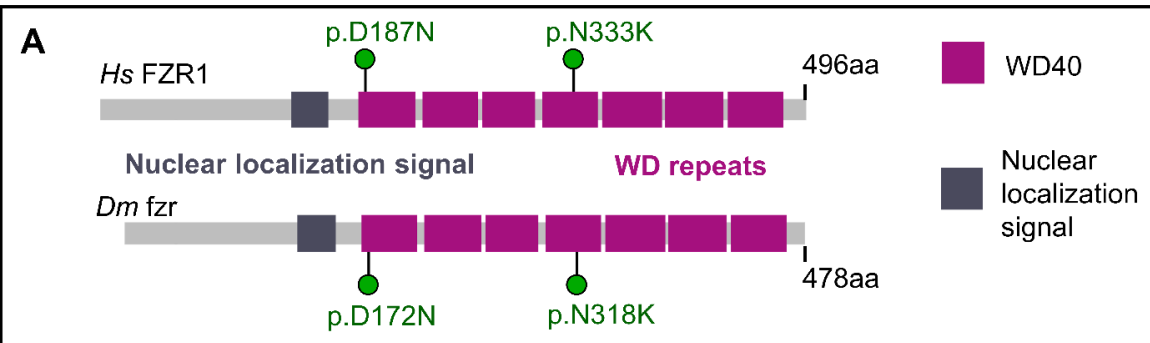

Hs FZR1 147 PYSLSPVSNKSQKLLRSPRKPTRK ISK IPFKVLDAPELQDDFYLNLVDW 195 $D m_{-} f z r \quad 132$ PYSLSPVSAKSQKLLRSPRKATRK ISRIPFKVLDAPELQDDFYLNLVDW 180

Hs FZR1 196 SSLNVLSVGLGTCVYLWSACTSQVTRLCDLSVEGDSVTS VGWSERGNLV 244 $D m_{-} f z r \quad 181$ SSQNVLAVGLGSCVYLWSACTSQVTRLCDLSPDANTVTSVSWNERGNTV 229

Hs_FZR1 245 AVGTHKGFVQIWDAAAGKKLSMLEGHTARVGALAWNAEQLSSGSRDRMI 293 $D m \_f z r \quad 230$ AVGTHHGYVTWDV VANKQ I NKLNGHSARVGALAWNSD I LSSGSRDRWI 278

Hs_FZR1 294 LQRDIRTPPLQSERRLQGHRQE VCGLKWSTDHQL LASGGNDNKLL WNH 342 $D m \mathrm{fzr} \quad 279$ IQRDTRTPQLQSERRLAGHRQE VCGLKWSPDNQYLASGGNDNRL YWNQ 327

B
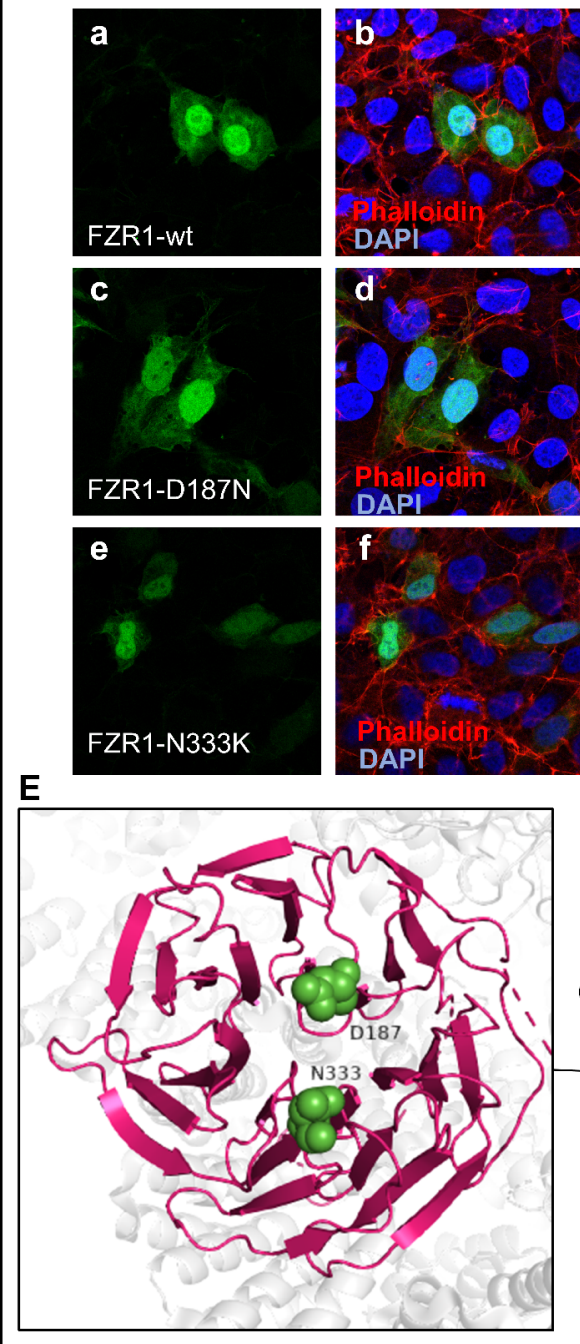

C
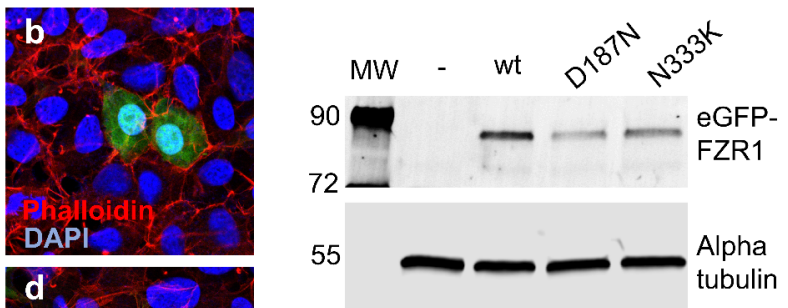

D
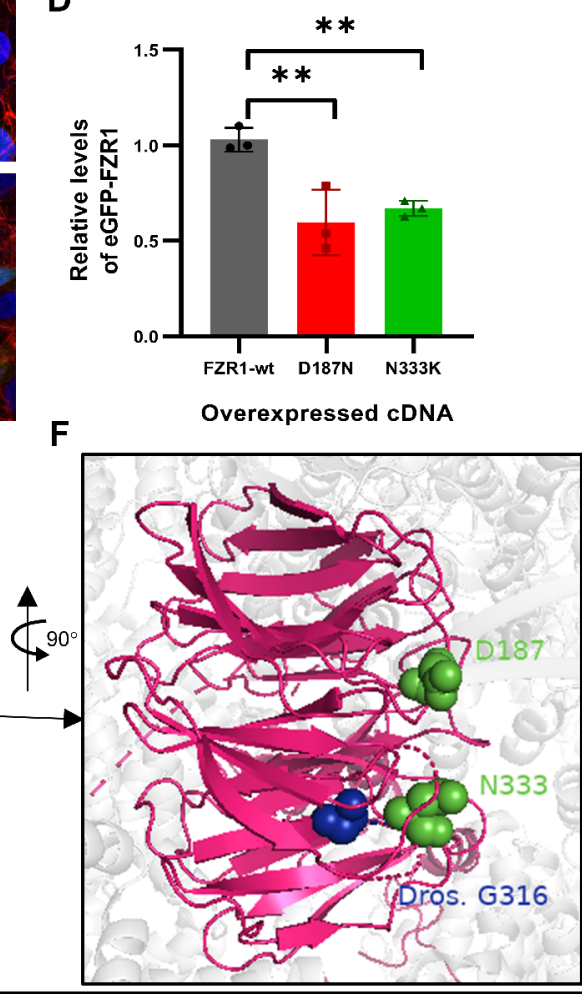
Figure 2

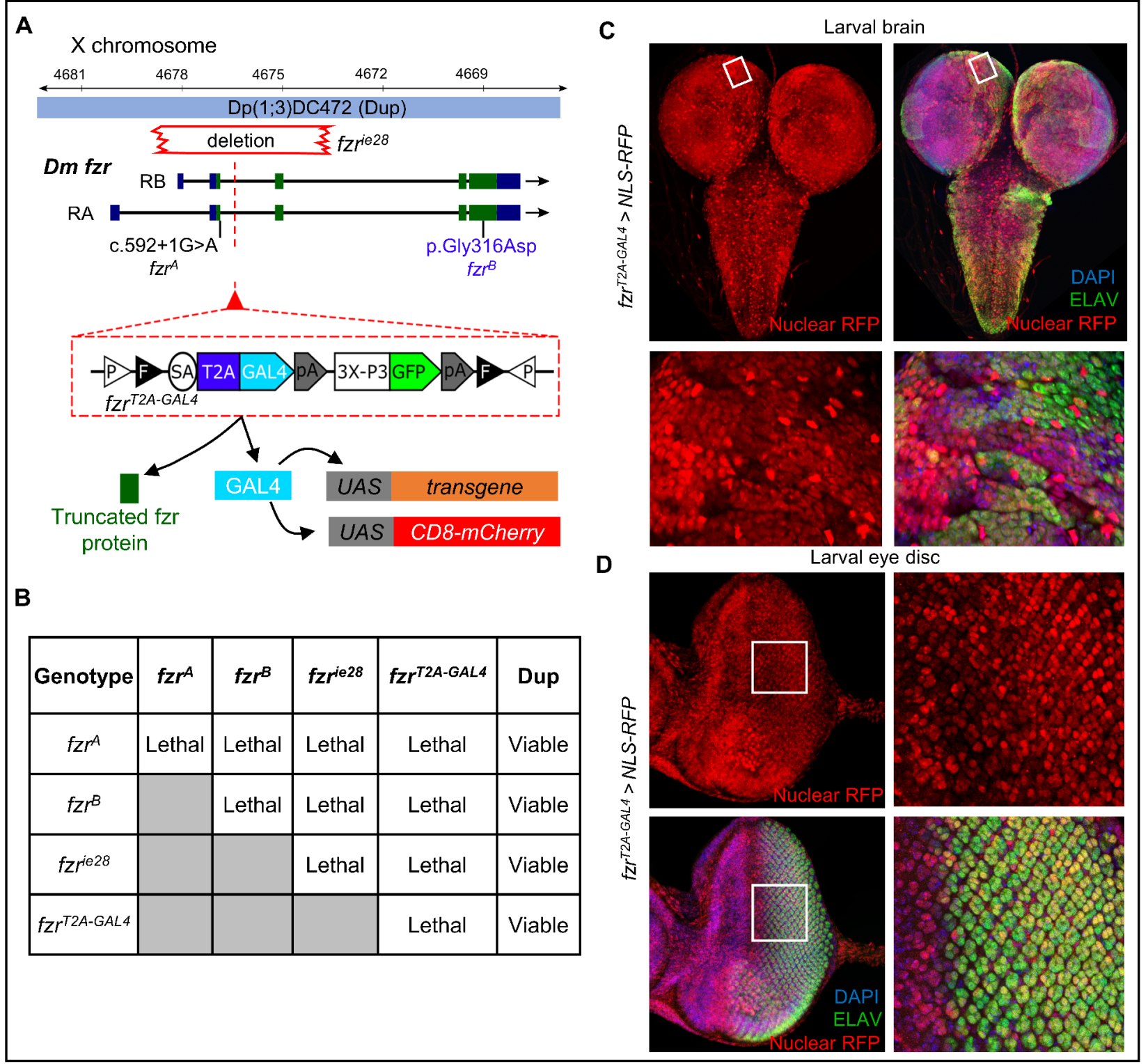


Figure 3

A

Eye imaginal disc (III instar larva)

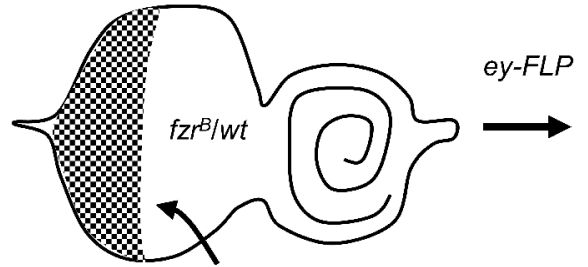

Stereotypic pattern of photoreceptor precursor cells
Mitotic mosaic cells

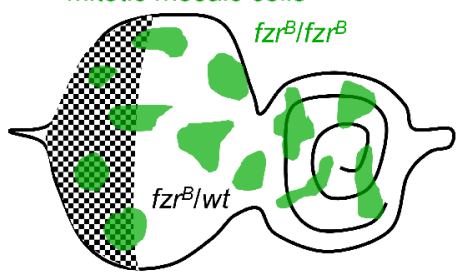

Pattern disruption in mosaic

mutants, rescue by overexpression of $\mathrm{fzr}$ wt or variant $\mathrm{CDNA}$
B

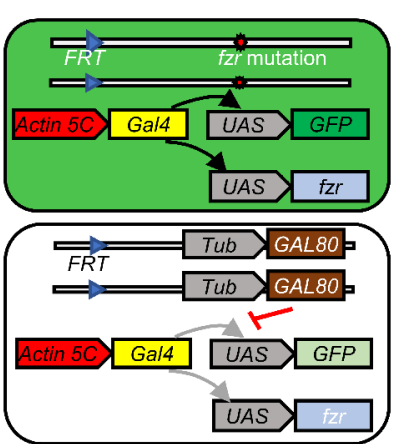

D
C

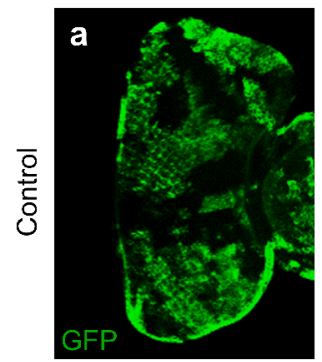

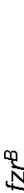

$\mathbf{E}$
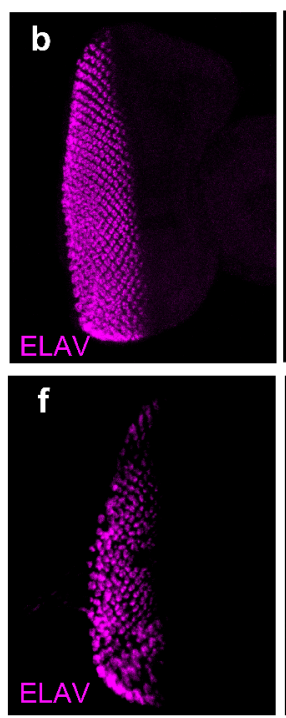
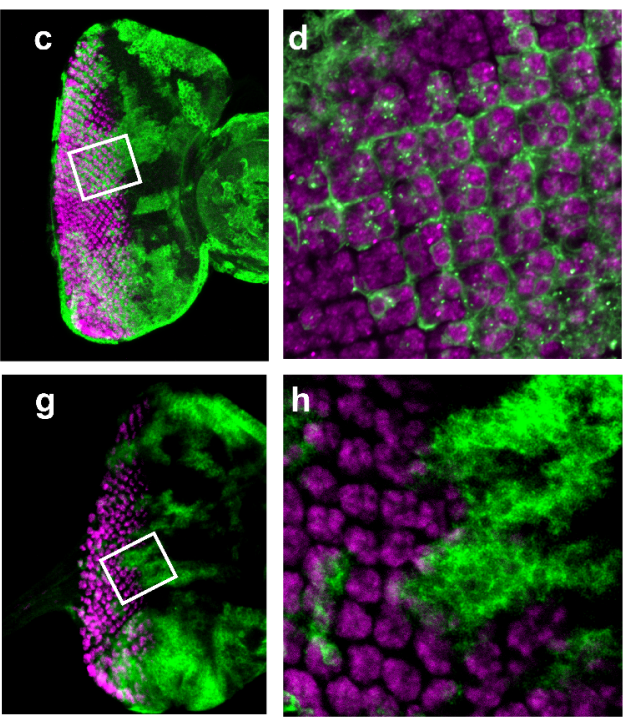
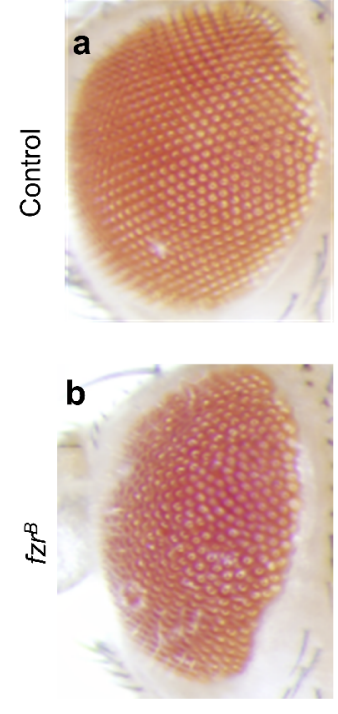

Glial migration defect and rescue

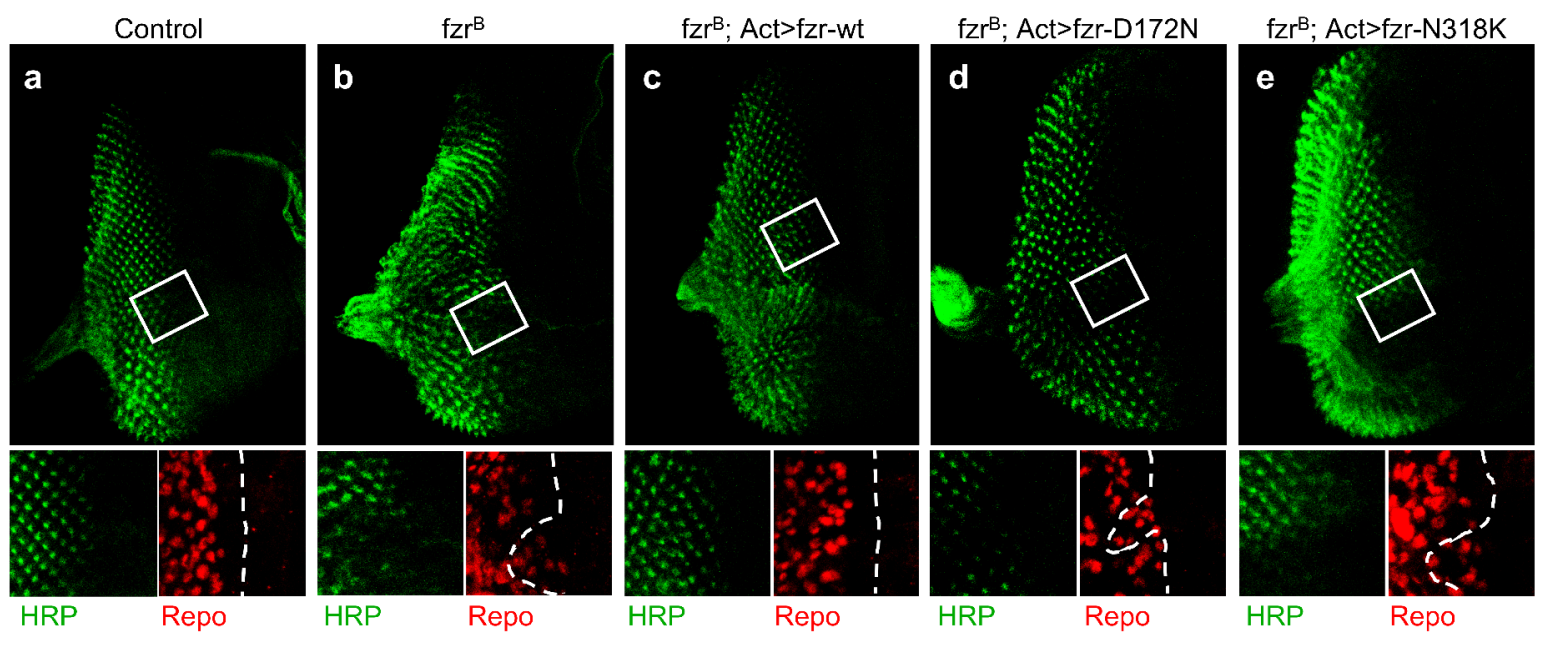


Figure 4

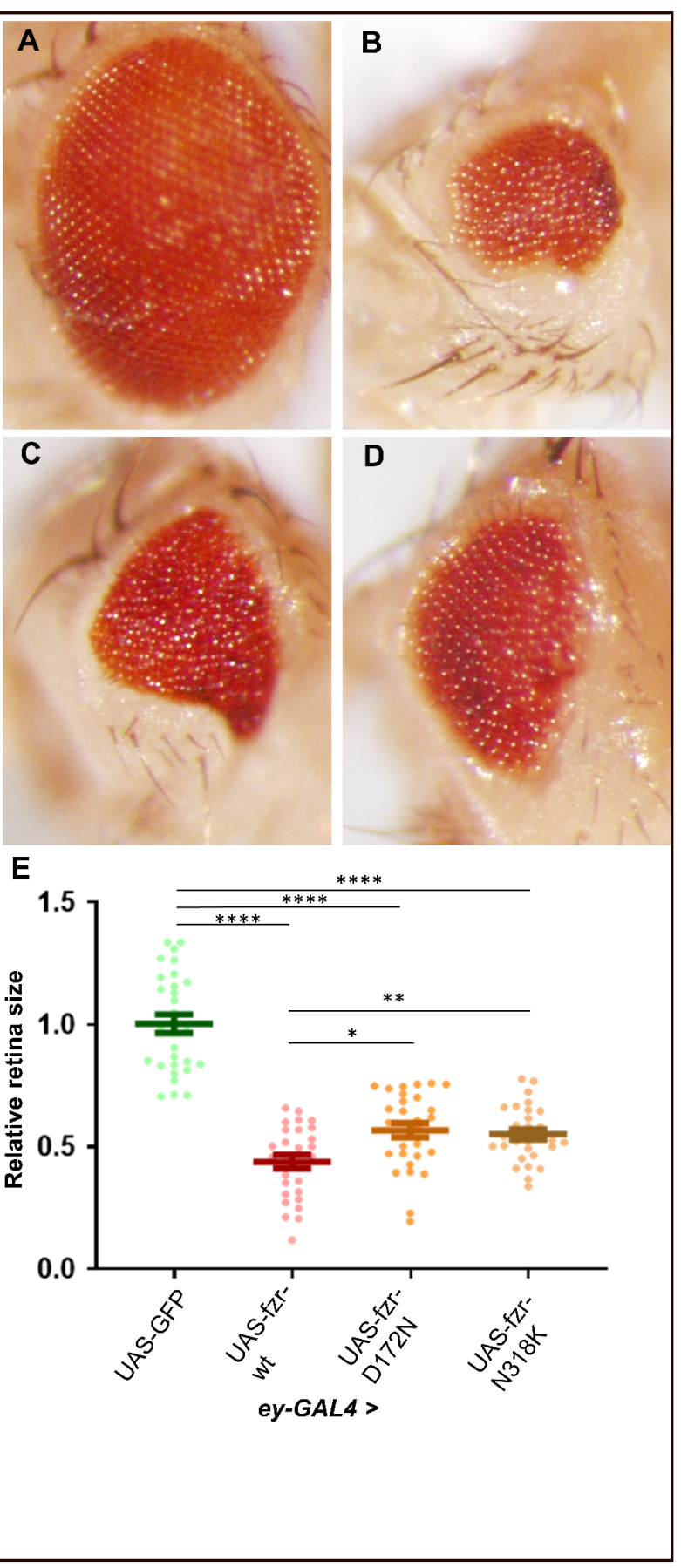


A

\section{CRIMIC-T2A GAL4 rescue}

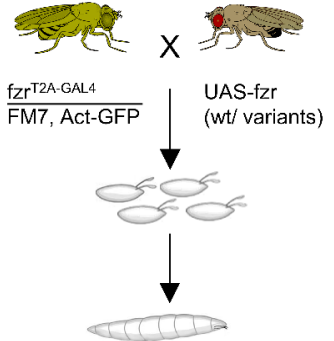

Rescued III instar male

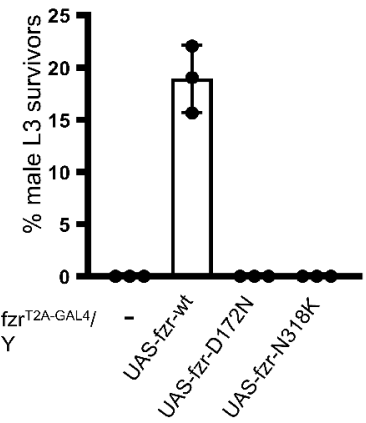

Embryonic CNS defects rescue
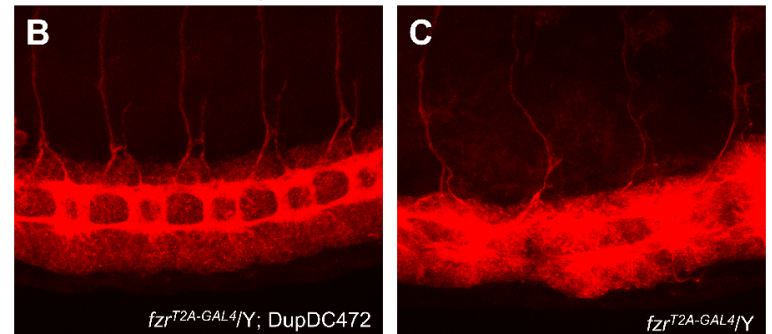

D

$f z r^{T 2 A-G A L 4} / Y ;$ UAS-fzr-wt

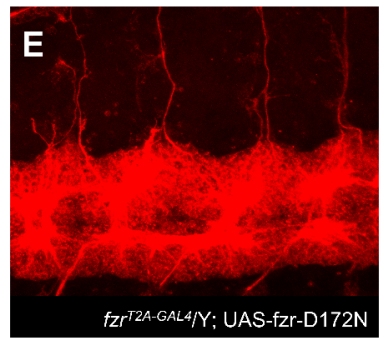

